\title{
laborhifórico
}

ISSN 2359-6910

https://revistas.ufrj.br/index.php/lh/

ARTIGO

Recebido em 21 de julho de 2019

Aprovado em 4 de setembro de 2019

\section{Amostras históricas do português escrito nos séculos XIX e XX: orientações metodológicas}

Historical samples of Portuguese written in the 19th and 20th centuries: methodological procedures

DOI: https://doi.org/10.24206/lh.v5i2.24452

Márcia Cristina de Brito Rumeu

Professora de Língua Portuguesa da FALE/UfMG e do Programa de PósGraduação em Estudos Linguísticos Faculdade de Letras, Universidade Federal de Minas Gerais. Belo Horizonte - MG - Brasil.

E-mail: mrumeu@ufmg.br ORCID: https://orcid.org/0000-0001-9254-976X

\section{Ana Luisa Póvoa de Souza}

Bolsista de Iniciação Científica do Projeto "Para uma Sociolinguística Histórica do Português Brasileiro: variação sincrônica e mudança diacrônica" e aluna do curso de Licenciatura em Letras (Português-Alemão) da Faculdade de Letras da Universidade Federal de Minas Gerais - UFMG, MG, Brasil.

E-mail: analuisapsouza@gmail.com ORCID: https://orcid.org/0000-0002-0199-1892 
Erenildo Queiroz de Sousa

Mestrando da Pós-Graduação em Estudos Linguísticos da Faculdade de Letras da Universidade Federal de Minas Gerais - UFMG, MG, Brasil.

E-mail: erenqueiroz@gmail.com

ORCID: https://orcid.org/0000-0002-5668-7425

Igor dos Reis Alcântara

Graduado no Curso de Bacharelado em Português com ênfase em Edição da Faculdade de Letras da Universidade Federal de Minas Gerais - UFMG, MG, Brasil.

E-mail: igor.dalcantara@gmail.com ORCID: https://orcid.org/0000-0002-5966-5985

Gabriela Vilela Souza Martins

Graduada no Curso de Bacharelado em Português com ênfase em Edição e aluna do curso de Graduação em Letras (Inglês) com ênfase em Linguística da Faculdade de Letras da Universidade Federal de Minas Gerais - UFMG, MG, Brasil.

E-mail: gabrielasvilelam@gmail.com ORCID: https://orcid.org/0000-0002-5602-2845

Juliana Sander Diniz

Mestre na área de Estudos Linguísticos da Faculdade de Letras da Universidade Federal de Minas Gerais.

E-mail: sanderdinizju@gmail.com ORCID: https://orcid.org/0000-0003-0625-6376

\section{Marcos Alexandre dos Santos}

Graduando do Curso de Bacharelado em Edição da Faculdade de Letras da Universidade Federal de Minas Gerais - UFMG, MG, Brasil.

E-mail: m.alexandre.s@outlook.com ORCID: https://orcid.org/0000-0002-1645-3608 
Natália Figueiredo Silva

Mestre na área de Estudos Linguísticos da Faculdade de Letras da Universidade Federal de Minas Gerais - UFMG, MG, Brasil.

E-mail: figues.natalia@gmail.com

ORCID: https://orcid.org/0000-0002-6317-8928

Natália Gontijo Alves

Licenciada no Curso de Português da Faculdade de Letras da Universidade Federal de Minas Gerais - UFMG, MG, Brasil.

E-mail: nataliagontijo.letras@gmail.com ORCID: https://orcid.org/0000-0001-7515-2015

Nayara Domingues Cardoso

Doutoranda na área de Estudos Linguísticos da Faculdade de Letras da Universidade Federal de Minas, Gerais - UFMG, MG, Brasil.

E-mail: nayaradominguesc@hotmail.com ORCID: https://orcid.org/0000-0003-4274-9194

Raissa Figueiredo

Graduada no Curso de Bacharelado em Português com ênfase em Estudos Linguísticos da Faculdade de Letras da Universidade Federal de Minas Gerais UFMG, MG, Brasil.

E-mail: raissafgd@gmail.com 


\section{RESUMO}

O objetivo deste artigo é apresentar o atual estágio do processo de constituição de corpora históricos para o estudo da língua portuguesa em terras mineiras no decorrer dos séculos XIX e XX. Com base na produção de conservadoras edições de documentos pessoais e oficiais, à luz das orientações teóricometodológicas de Bergs (2005); Conde Silvestre (2007); Hernández-Campoy e Conde Silvestre (2012), buscamos expor algumas evidências de edições de atas, estatutos confrariais, receitas culinárias e cartas pessoais produzidas por mineiros entre os séculos XIX e XX. A proposta é a de apresentar amostras históricas representativas dos acervos históricos de Minas Gerais até o momento levantadas e estudadas no âmbito da FALE/UFMG, tendo em vista, por exemplo, o fato de as cartas mais íntimas (familiares e amorosas) mostrarem-se preferencialmente mais transparentes em relação à explicitação de traços linguísticos da norma de uso (CUNHA, 1985) do PB, cf. discutido por Rumeu (2013). Em contrapartida, nas atas do IHGMG e nos estatutos confrariais, prevemos a expressão não só da escrita culta mineira cujo contexto de escritura é de elevado grau de formalismo, mas também de pistas do contexto histórico-social. Acreditamos, pois, em conformidade com Lobo (2001), que conservadoras edições de manuscritos históricos (oficiais ou não-oficiais) correspondam aos desejos do linguistapesquisador ávido por fontes fidedignas ao estudo da estruturação da pluralidade de normas do português brasileiro, cf. Callou, Barbosa e Lopes (2006).

Palavras-chave: Crítica textual. Corpora históricos. O método na sociolinguística histórica. Filologia. Paleografia.

\section{ABSTRACT}

The objective of this article is to present the current stage of the process of constitution of historical corpora to the study of the Portuguese language in lands of Minas Gerais during the nineteenth and twentieth centuries. Based on the production of conservative editions of personal and official documents, in the light of the theoretical-methodological procedures of Bergs (2005); Conde Silvestre (2007); Hernández-Campoy; Conde Silvestre (2012), we seek to present some evidence of editions of minutes, culinary recipes and personal letters produced by Miners between the nineteenth and twentieth centuries. The proposal is to present historical samples representative of the Minas Gerais historical collections up to the present time and studied in FALE / UFMG, considering, for example, the fact that the most intimate letters (family and love) are shown as more transparent in relation to the explication linguistic features of the usage rule of PB (CUNHA, 1985), cf. discussed by Rumeu (2013). On the other hand, in the minutes of the IHGMG and in the confraternities, we predict the 
expression not only of educated mining in Minas Gerais, whose context of writing is of a high degree of formalism, but also of features to the historical-social context. According to Lobo (2001), we believe that conservative editions of historical manuscripts (official or unofficial) correspond to the desires of the linguist-researcher eager for reliable sources to study the structure of the plurality of Brazilian Portuguese standards, cf. Callou, Barbosa and Lopes (2006).

Keywords: Textual criticism. Historical corpora. Method in sociolinguistic historical. Philology. Paleography. 


\section{Considerações iniciais}

Neste artigo, pretendemos, de um modo geral, apresentar amostras históricas representativas dos acervos mineiros até o momento levantadas e estudadas no âmbito do projeto "Para uma Sociolinguística Histórica do Português Brasileiro: variação sincrônica e mudança diacrônica" desenvolvido na FALE/UFMG. A ideia geral é expormos o estado da questão em termos de constituição de corpora confiáveis e representativos da expressão escrita do português brasileiro (doravante PB) em terras mineiras de sincronias passadas. Em termos mais específicos, também visamos à apresentação de uma proposta de protocolo metodológico para as pesquisas no âmbito da sociolinguística histórica (BERGS, 2005; CONDE SILVESTRE, 2007; HERNÁNDEZ-CAMPOY; CONDE SILVESTRE, 2012).

O estudo da norma brasileira do português escrito está vinculado à edição de amostras históricas confiáveis aos estudos linguísticos. Nesse sentido, colocamos em cena o processo de edição de corpora representativos do português produzido preferencialmente por mineiros entre fins do século XIX e fins do século XX. Nesta abordagem panorâmica, trazemos amostras históricas compostas por estatutos confrariais, atas do Instituto Histórico e Geográfico de Minas Gerais (doravante IHGMG), receitas culinárias e cartas pessoais. Em relação às amostras de textos oficiais, temos não só as edições fac-similares e diplomáticas das atas confrariais dos Estatutos da Archi-Confraria de Santo Antônio de Pádua (1849), mas também as atas do IHGMG (1907). Descrevemos ainda as conservadoras edições de receitas culinárias compiladas no início do século XX e das amostras de cartas pessoais (amor, amizade, familiar) produzidas entre fins do século XIX e fins do século XX. Em síntese, as amostras dos estatutos confrariais, atas novecentistas, receitas culinárias e cartas pessoais estão panoramicamente descritas neste texto.

Assumimos como ponto de partida alguns princípios da sociolinguística histórica como fundamentação teórico-metodológica, a fim de encaminharmos a discussão acerca de um protocolo metodológico para as pesquisas históricas. Estruturalmente, este texto está organizado em cinco seções. $\mathrm{Na} 1^{a}$ seção, justificamos a preferência pela edição fac-similar e diplomática de manuscritos históricos principalmente do ponto de vista da crítica textual (CARVALHO E SILVA, 1994, p. 59-60). Na $2^{\mathrm{a}}$ seção, expomos os fundamentos da sociolinguística histórica relacionando-os ao processo de formação de corpora históricos. $\mathrm{Na} 3^{a}$ seção, tratamos não só dos estatutos confrariais oitocentistas, mas também das atas novecentistas editadas, respectivamente, por Alcântara (2018) e Silva (2016). A $4^{a}$ seção está voltada para as edições de receitas culinárias novecentistas (1905 e 1906) editadas por Martins (2017) e por Santos (2018). Na $5^{a}$ seção, voltamos o foco para a apresentação da edição das cartas pessoais oitocentistas e novecentistas que embasaram as análises linguísticas em formato de dissertações (CARDOSO, 2017; CRUZ, 2017; DINIZ, 2018), monografias de fim de curso de graduação 
(FRANÇA, 2016; COSTA, 2014, FIGUEIREDO, 2013) e de pôsteres de iniciação científica ${ }^{1}$. Por fim, expomos, em síntese, alguns encaminhamentos metodológicos que podem auxiliar o processo de seleção, edição e análise de amostras linguísticas confiáveis aos estudos no âmbito da sociolinguística histórica.

\section{A preferência pelas edições fac-similar e diplomática de manuscritos históricos}

Considerando a polissemia do termo filologia já abordada por Vasconcellos e Santiago-Almeida (2012, p. 336), Santiago-Almeida (2009, p. 223), Carvalho e Silva (1994), entendemos que é típico do fazer filológico o trabalho com o texto escrito de uma forma mais ampla e diversificada, cf. Vasconcellos e Santiago-Almeida (2012, p. 336), uma vez que "a palavra filólogo, pela sua polissemia, não se aplica exclusivamente a quem se dedica à crítica textual”, cf. Carvalho e Silva (2002, p. 70). De outro modo, assumimos, em conformidade com Carvalho e Silva (1994) à luz da filóloga Luciana Stegagno Picchio, que compete ao crítico textual a reconstrução do texto de forma irrestrita não contribuindo tão somente como um "mero preparador de textos a serem entregues depois, prontos para a interpretação, a um pesquisador de grau superior, identificável com o crítico literário", cf. Carvalho e Silva (1994, p. 61). Assim sendo, apropriamo-nos das seguintes atribuições do crítico textual, expostas e discutidas por Carvalho e Silva (1994).

- A pesquisa da gênese dos textos (...) que possa contribuir para as conclusões sobre o labor autoral.

- A fixação de princípios que devem orientar o trabalho da reprodução e da elaboração de todos os tipos de edições de textos.

- A preparação de edições fidedignas ou de edições críticas, enriquecidas, sempre que recomendável, de estudos prévios, notas explicativas ou exegéticas destinadas a valorizar o labor autoral.

(CARVALHO E SILVA, 1994, p. 59-60)

\footnotetext{
${ }^{1}$ a. Natália Gontijo Alves. As estratégias pronominais de complementação verbal de $2 S G$ na escrita mineira (séculos XIX e XX). 2018. Apresentação de Pôster de Iniciação Científica na XXVI Semana de Iniciação Científica. Faculdade de Letras da UFMG.

b. Marina Costa Marçal de Moraes. As construções imperativas de $2^{a}$ pessoa do singular na escrita mineira novecentista. 2017. Apresentação de Pôster de Iniciação Científica na XXV Semana de Iniciação Científica. Faculdade de Letras da UFMG, Fundação de Amparo à Pesquisa do Estado de Minas Gerais (FAPEMIG).

c. Priscilla Raquel Ribeiro de Freitas. As formas variantes dos sintagmas possessivos de $2^{a}$ pessoa do singular (teu versus seu) no português brasileiro. 2017. Apresentação de Pôster de Iniciação Científica na XXV Semana de Iniciação Científica. Faculdade de Letras da UFMG, Fundação de Amparo à Pesquisa do Estado de Minas Gerais (FAPEMIG).

d. Juliana Sander Diniz. As Construções de Imperativo de $2^{a}$ pessoa do singular na produção escrita brasileira: a influência dos fatores linguísticos. 2015. Apresentação de Pôster de Iniciação Científica na XXIV Semana de Iniciação Científica. Faculdade de Letras da UFMG, Fundação de Amparo à Pesquisa do Estado de Minas Gerais (FAPEMIG).
} 
Uma vez apresentada a distinção entre os conceitos de filologia e crítica textual com base nas funções do filólogo e do crítico textual, passamos a uma breve caracterização, à luz de Spina (1977), da edição fac-similar e diplomática ${ }^{2}$ proposta para documentos históricos oitocentistas e novecentistas em foco neste texto. Considerando o fato de que este trabalho de edição está orientado pelo objetivo maior de contribuir para a formação de amostras históricas do PB escrito em sincronias passadas, acreditamos que as especificidades dos gêneros textuais estatutos confrariais, atas, cartas pessoais e receitas culinárias as evidenciam como amostras sui generis para o estudo do PB escrito, o que justifica as conservadoras edições de tais documentos históricos produzidos, em sua maioria, por punhos mineiros entre fins do século XIX e fins do século XX. Assumindo como ponto de partida o fato de que as edições das amostras históricas em análise embasarão análises linguísticas, sustentamo-nos, em conformidade com Faria e Pericão (2008), no objetivo de legitimar ao leitor a possibilidade de confrontar a edição proposta com o fac-símile do documento para conferir até que ponto a interpretação do editor em relação ao grafema manuscrito está ou não de acordo com a imagem do seu fac-símile (edição fac-similar). Assim sendo, empenhamo-nos na divulgação acadêmica de edições fac-similares desprovidas de intervenções e/ou modernizações no decorrer do processo de transcrição dos originais manuscritos (edição diplomática), cf. Faria e Pericão (2008).

- EDIÇÃO FAC-SIMILADA - A que reproduz a edição original exatamente, quer no texto, quer nas ilustrações; costuma-se fazer-se de textos com valor documental, particularmente de textos manuscritos que se reproduzem por processos fotomecânicos.

(FARIA; PERICÃO, 2008, p. 432)

-EDIÇÃO DIPLOMÁTICA - A que reproduz escrupulosamente um determinado exemplar (ou o exemplar único) de um texto; nela procura dar-se conta de todas as particularidades materiais e gráficas sem interpretação ou modificação por parte do editor; esta operação é feita após o estabelecimento crítico do texto, tendo em vista a tradição deste e a crítica da sua autenticidade e data.

(FARIA; PERICÃO, 2008, p. 430)

Passamos à apresentação das edições dos documentos históricos em foco (atas, estatutos confrariais, receitas culinárias, cartas pessoais), caracterizando não só as amostras, mas também o fazer filológico voltado para as edições fac-similares e diplomáticas à luz dos princípios teóricometodológicos da crítica textual (Spina, 1977; Nuñez Contreras, 1994; Berwanger e Franklin Leal, [1995] 2008; Spaggiari e Perugi, 2004), ainda que tenhamos lidado com fontes históricas monotestemunhais.

\footnotetext{
${ }^{2}$ A edição dos documentos oitocentistas e novecentistas em foco se deu com base em parâmetros específicos para a transcrição dos manuscritos que inspirados principalmente em Rumeu (2013) e Lobo (2001) orientam o Projeto "Para a História do Português Brasileiro".
} 


\section{A constituição de corpora do passado: os fundamentos da sociolinguística histórica}

O processo de reconstituição histórica das línguas humanas em sincronias passadas passa pelo trabalho de levantamento e análise de amostras escritas remanescentes, considerando sempre os possíveis traços de hipercorreção, mistura dialetal e "erros" do escriba (LABOV, 1994, p. 11) que poderiam misturar-se aos traços fidedignos de uma dada realidade linguística pretérita. Além disso, temos o fato de que, em amostras históricas (atas, estatutos confrariais, cartas pessoais, receitas culinárias), só podemos acessar os dados positivos, ou seja, as ocorrências linguísticas textualmente produzidas. Obviamente, o que não está no texto escrito não quer dizer que não fazia parte da norma de uso de uma dada sincronia pretérita. Assim sendo, o linguista-pesquisador somente tem acesso indireto às realidades linguísticas pretéritas através dos traços grafo-fonéticos, morfossintáticos e semântico-lexicais do PB escrito em sincronias passadas, o que necessariamente repercute na preocupação com o "problema dos filtros” (ROMAINE, 1982), ou seja, no cuidado em separar traços da língua oral que tendam a se misturar com traços da língua escrita (AGUILLAR, 1998).

(...) A presença do oral na escrita é inegável, se intue, e às vezes é possível inclusive demonstrar-se: mas todo discurso é misto, impuro e do mesmo modo que a oralidade pode impregnar certos tipos de escrita, também as práticas de escrita podem infiltrar-se na oralidade. $(. . .)^{3}$

(AGUILLAR, 1998, p. 239-240.)

Como uma investigação no âmbito da sociolinguística histórica só pode valer-se de corpora escritos, é importante refletirmos sobre o(s) gênero(s) e subgênero(s) textuais mais propícios à expressão do PB vernacular. Seguindo a perspectiva do modelo de Koch e Oesterreicher (1985, 1994 apud ELSPASS, 2012), assumimos os gêneros textuais do meio escrito no continuum delineado entre os polos dos textos do 'imediatismo', como uma conversa íntima, e da 'distância', assim como um contrato em termos legais. Assim sendo, interpretamos o gênero textual carta pessoal e os seus subgêneros familiares, amorosas e de amizade como mais aproximadas da "língua do imediatismo", visto que tendem a expor com um maior nível de transparência traços do vernáculo do PB.

Os estudos em sociolinguística histórica não passam pela transposição da metodologia sociolinguística laboviana stricto sensu, o que nos leva a ponderarmos também sobre a percepção do vernáculo do $\mathrm{PB}$ através da escrita, atentando ao(s) gênero(s) (atas e receitas culinárias) e subgênero(s) textual(is) (cartas amorosas, familiares e de amizade) mais propensos à explicitação do vernáculo do $\mathrm{PB}$,

\footnotetext{
${ }^{3}$ (...) La presencia de lo oral en lo escrito es innegable, se intuye, y a veces puede incluso demostrarse: pero todo discurso es mixto, impuro, y del mismo modo que la oralidad puede impregnar ciertos tipos de escritura, también los modos escriturarios pueden infiltrarse en la oralidad. (...) (AGUILLAR, 1998, p. 239-240.)
} 
visto que as fontes históricas tendem a ser "fragmentárias, escassas e dificilmente vinculáveis com a produção real de seus falantes” (CONDE SILVESTRE, 2007, p. 35). Como compete ao linguistapesquisador o comprometimento ético com a pesquisa histórica, descrevemos alguns parâmetros (autoria, autenticidade ${ }^{5}$ e validade social e histórica) que tendem a conduzir os resultados das análises embasadas em amostras históricas (HERNÁNDEZ-CAMPOY; SCHILLING, 2012). Nesta seção, focalizaremos, ainda em termos de fundamentação teórica no âmbito da sociolinguística histórica, a interpretação do gênero textual carta pessoal (amorosas, familiares e de amizade) em relação às questões da autoria, autenticidade e validade social e histórica da fonte, tendo em vista se tratar de um gênero textual e de seus subgêneros que se aproximam da "língua do imediatismo". A partir da $3^{\text {a }}$ seção, retomamos a discussão mais pormenorizada em relação aos gêneros atas, receitas culinárias e cartas pessoais, tendo em vista as especificidades das amostras mineiras.

A autoria dos textos históricos é a certificação sobre o fato de o texto ter sido escrito pela própria mão de quem o assinou (testemunho autógrafo), por um punho distinto daquele de quem o assinou (testemunho apógrafo) ou ainda produzido por outra pessoa (testemunho idiógrafo), ainda que sob a supervisão do autor (autoria intelectual).

Assim sendo, as análises no âmbito da sociolinguística histórica sustentam-se também nas potencialidades da paleografia, caracterizando uma perspectiva interdisciplinar ao processo de edição de corpora históricos. Neste artigo, apresentamos os resultados relacionados principalmente aos processos de levantamento, transcrição e análise das missivas pessoais (amorosas, familiares e de amizade) produzidas e assinadas por escreventes nascidos no espaço geográfico de Minas Gerais, assim como voltamos o foco para a questão da autoria das atas históricas e das receitas culinárias em análise.

Se, por um lado, o gênero textual carta pessoal (e os seus subgêneros) é marcado pelos traços de uma interação dialógica (ELSPASS, 2012, p. 162), é possível que a variação identificada nas cartas não evidencie fidedignamente o vernáculo do PB. A autenticidade ${ }^{6}$ da fonte histórica é um aspecto que deve ser perseguido pelo linguista-pesquisador justamente porque o registro escrito pode estar marcado pela expressão da norma-padrão, ainda que, por outro lado, seja passível de evidenciar traços de hipercorreção, mistura dialetal e "erros" do escriba cf. Labov (1994, p. 11). Nesse sentido, é tarefa do linguista-pesquisador a devida percepção acerca do que é mesmo reflexo do vernáculo do escriba

\footnotetext{
4 "En comparación con la diversidad, cantidad y autenticidad de los datos a disposición del investigador en sociolingüística sincrónica o en lingüística descriptiva, la información de que dispone quien intenta desarrollar su investigación en el ámbito de la lingüística o la sociolingüística histórica es fragmentaria, escasa y difícilmente vinculable con la producción real de sus hablantes." (CONDE SILVESTRE, 2007, p. 35.)

${ }^{5}$ É importante esclarecermos que o uso do termo "autenticidade" deu-se no sentido de "legitimidade" da fonte histórica em relação à real expressão da norma de uso (vernáculo) do redator de sincronias passadas, cf. Elspass (2012).

${ }^{6}$ Utilizamos o termo "autenticidade" não na perspectiva da Diplomática, mas concebemos a "autenticidade" no sentido da fidedignidade do registro escrito em relação ao vernáculo de uma dada realidade linguística pretérita em conformidade com a perspectiva de análise da sociolinguística histórica (ELSPASS, 2012).
} 
em relação ao que pode ser traço específico do gênero textual. A questão da autenticidade das cartas pessoais, por exemplo, não pode ser desconsiderada, se levarmos em conta o alto nível de escolaridade dos missivistas, ainda que os contextos distensos e íntimos das relações sociais que as conduzem sejam propícias às análises sobre a expressão vernacular do PB.

No âmbito dos trabalhos em sociolinguística histórica, faz todo o sentido a reconstituição dos perfis biográficos dos escreventes com o intuito de explicarmos os níveis de variação e mudança linguísticas. Todavia, a tarefa de asseguramento da validade social e histórica das fontes documentais é, por vezes, laboriosa, já que "geralmente sabemos muito pouco sobre a posição social dos informantes, e não mais acerca da estrutura social da comunidade" "LABOV, 1994). No que se refere especificamente às cartas íntimas, constatamos serem os acervos de ilustres escreventes uma excelente fonte de pesquisas históricas, já que desses informantes é possível resgatarmos as suas informações biográficas. Com o intuito de legitimarmos a validade social e histórica de determinada fonte documental, passamos pelo trabalho de reconstrução do perfil biográfico do escrevente (no interior dos arquivos através das suas fontes primárias e em fontes de pesquisa biográfica tais como índices genealógicos, dicionários biográficos e instrumentos de pesquisa) que, por sua vez, está diretamente relacionado ao fato de lidarmos com fontes originais autógrafas principalmente no caso das cartas pessoais. Com base nesse tipo de averiguação linguístico-paleográfico que também passa pela preocupação com a autoria e, consequentemente, com a validade social e histórica da fonte manuscrita, passemos à análise das amostras mineiras.

\section{A edição de atas e de estatutos confrariais: a opção pela edição fac-similar e diplomática}

Nesta seção, passamos à uma breve apresentação das edições dos documentos históricos em análise, quais sejam: atas do IHGMG (1907), estatutos confrariais (1849), cartas pessoais oitocentistas e novecentistas (1869 e 1989) e receitas culinárias novecentistas (1905 e 1907). A opção pela edição facsimilar e diplomática desses documentos está justificada na produção de conservadoras edições voltadas aos estudos sociolinguísticos sobre a expressão escrita do português nos séculos XIX e XX. Ao expormos o fac-símile ao lado da transcrição, permitimos que o linguista-pesquisador possa conferir a interpretação do código escrito. Considerando a opção também pela edição diplomática cuja intervenção do editor é praticamente nula, apresentamos à comunidade acadêmica transcrições rigorosamente de acordo com os traços paleográficos e linguísticos das sincronias passadas em foco.

\footnotetext{
7 "(...) we usually know very little about the social position of the writers, and not much more about the social structure of the community”.
} 


\subsection{Os estatutos da Archi-Confraria de Santo Antônio de Pádua (1849)}

Os Estatutos da Archi-Confraria de Santo Antônio de Pádua (1849) estão formalmente organizados em um códice mantido sob a guarda do IHGMG. Assumimos a contribuição de Alcântara (2018) em relação à conservadora edição fac-similar e diplomática desse conjunto de textos oitocentistas (imagens 01 e 02) cuja relevância histórica está não só na expressão dos mecanismos internos de organização de uma irmandade católica no Brasil da $1^{\text {a }}$ metade do século XIX (1849), mas também em relação à sua expressão escrita na realidade da língua portuguesa do Brasil oitocentista.

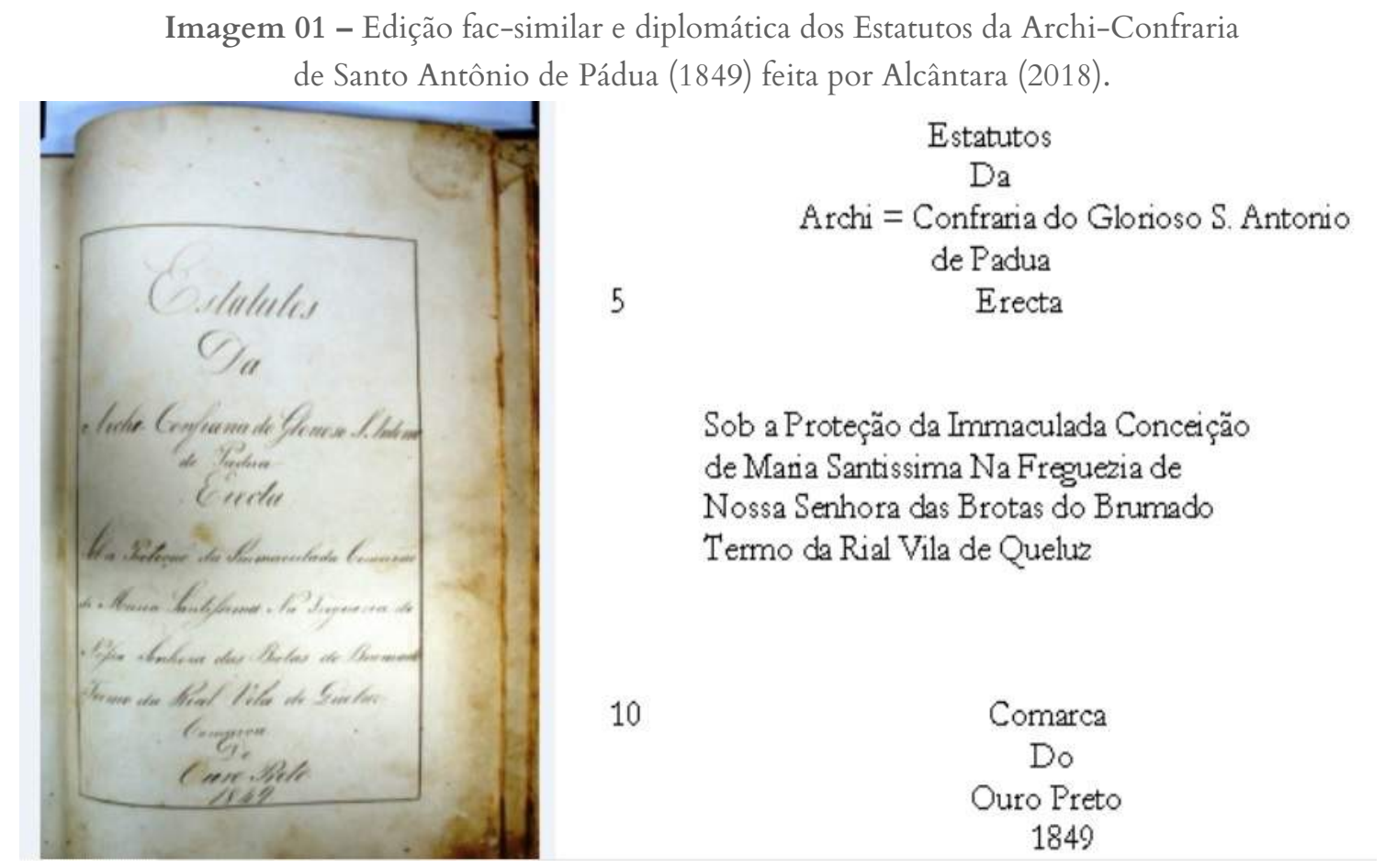

Estruturalmente, o códice dos Estatutos da Archi-Confraria de Santo Antônio de Pádua do IHGMG é composto por quarenta e dois (42) fólios distribuídos por 32 capítulos (do fólio 1 recto até o fólio 32 recto) seguidos por alguns documentos, tais como, abaixo-assinado dos Mezários (fólio 33 recto), Documento de Aprovação do Compromisso da Irmandade Religiosa (entre os fólios 34 recto e verso), Documento de Confirmação do Compromisso (fólios 35 recto e verso), Abaixo-assinado pelos membros da Irmandade em relação ao artigo $26^{\circ}$ do Compromisso (fólio 36 recto), Delegação apostólica em relação à concessão de Indulgência Plenária aos irmãos, em 16 de abril de 1850 (fólio 37 recto), Concessão da Indulgência Plenária, em 20 de junho de 1854 (fólio 38 recto), Concessão de Indulgência Plenária, em 09 de junho de 1874 (fólio 39 recto), Relação nominativa intitulada "Matrícula geral dos Irmãos Remidos" (fólio 40 recto e fólio 42 recto). 
De um modo geral, os estatutos confrariais, produzidos em suporte cartáceo marcados por um tom amarelado, expõem as regras estabelecidas por uma Irmandade Católica oitocentista para promover a dinâmica dos seus cultos a Santo Antônio de Pádua (1849), na Comarca de Ouro Preto. Apesar de os trinta e dois (32) capítulos dos estatutos confrariais terem sido produzidos pelo punho de Bhering ("Antonio José Ribeiro Bhering”), responsável por rubricar todos fólios como um legítimo Secretário interino ${ }^{8}$, é possível, com base na análise do fólio 26 recto (imagem 02), observar não só a mudança de punho no decorrer do mesmo fólio, tendo em vista o Despacho redigido pelo Secretário "Bhering”, mas também o curso legível desse traçado no decorrer dos demais capítulos, o que permite caracterizar como hábil o punho do redator dos capítulos dos estatutos em relação ao contato e ao domínio com os modelos de escrita, cf. Marquilhas (1996, 2000).

\section{Imagem 02 - Fólio 26r.}

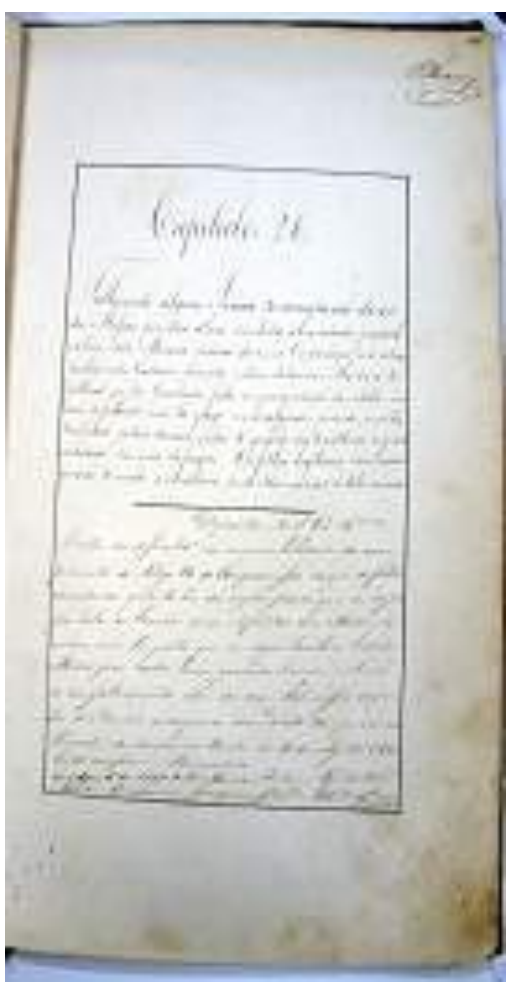

[fól. 26r]

Capitulo $=26 . \quad \begin{array}{r}26 \\ \text { Bhering. }\end{array}$

Fallecendo a glum Irmäo se mandaräo dizer

dez Missas por sua ama com toda aberidade possivel,

235 esetiver sido Mezario sedirão dore, ea Corporação irá acom panhar oseo cedaver, havendo enterio solemne, ethe dará se= pultura em seo cemiterio, féta a encomendaçäo do estillo; eno cazo dofallecido não ter pago courza alguma, podendo, enão ter cumprido os seos deveres, entz̃o só gozará da sepultura eincom

240 mendação sem mais sufragio. [espaço] Os filhos legitimos dos Imäos gozarão só mente de sepultura, sendo elles menores de sete annos.

\section{Despacho deSEx $x^{\mathrm{P}} \mathrm{R}^{\mathrm{m}}$}

$A^{\prime}$ vista da difficuldade ou impossibilidade do cum= primento do Attigo 26 do Compromisso de que sefalla

245 concedemos quanto he danossa parte, que se digão por todos os Irmãos vivos edefuntos cem Missas an nuais, mas he justo que se diga tambem huma Missa por cada hum quando houver noticia de seu fallecimento alem das cem. Este nosso despa

250 cho se deverá incorporar com odito Compromisso Piedade de sima em [Vereta] aos 4 de Agosto 1850 Está conforme Brumado 12 de Agosto de 1850. OSecretario da Antonio Bp ${ }^{\circ}$ daMar. ${ }^{\text {na }}$ Archi-Confraria. Joaquim José de Olivi ${ }^{2}$ Pennido

70 trecho que neste ponto se inicia foi escrito por outro punho e assinado pelo Secretário da Archi-Confraria, Joaquim José de Olivi².

\footnotetext{
${ }^{8}$ Em conformidade com o Termo de Provisão de confirmação do Compromisso da Archi Confraria do Glorioso Santo Antonio de Padua (fól. 35r) anexado ao códice em análise.
} 
Acreditamos que a conservadora edição dos Estatutos da Archi-Confraria do Santo Antônio de Pádua (1849) concorra para a discussão acerca da reconstrução da história linguística e da história social do português no e do Brasil do século XIX. A contribuição do trabalho de edição em questão é comprovada não só pelo levantamento e pela comparação entre os punhos (autoria e autenticidade, cf. Elspass (2012)) dos responsáveis pela redação do códice em foco, mas também pela reconstituição da configuração social dos brasileiros que se mantiveram unidos através de uma irmandade católica, o que acaba por evidenciar a validade social e histórica dos estatutos confrariais.

\subsection{As Atas do Instituto Histórico e Geográfico de Minas Gerais}

Em 16 de junho de 1907, na Câmara dos Deputados do Congresso Mineiro fomentado pelas diretrizes e objetivos do "Club Floriano Peixoto", o IHGMG foi criado com o intuito de "congregar intelectuais interessados em estudos de História e Geografia”, cf. Lasmar (2015, p. 124). O direcionamento da instituição é exposto pelo Dr. Augusto de Lima que, em seu discurso de instalação e posse dos membros do IHGMG, comentou acerca do seguinte intuito fomentado ainda no Clube Floriano Peixoto: “(...) formação de um nucleo intellectual entre nós para o estudo consciencioso do nosso passado historico" (fólio 1v:50-51). Em 12 de julho de 1907, foi eleita a primeira Diretoria do IHGMG cujos ilustres membros tiveram o seu perfil biográfico levantado e descrito, tendo em vista a edição fac-similar e diplomática das atas do IGHMG (entre os fólios 1 e 36) feita por Silva (2016). Trata-se de uma edição (imagem 03) que contribui não só para a preservação da expressão históricosocial do pensamento da elite intelectual mineira no século XX, mas também para análises linguísticas no âmbito da sociolinguística histórica (cf. CONDE SILVESTRE, 2007; HERNÁNDEZ-CAMPOY E CONDE SILVESTRE, 2012). Assumimos, também em harmonia com Condé (2009, p. 235), a relevância da propagação de estudos linguísticos diacrônicos com base em fontes documentais primárias, visto que podem permitir "uma identificação entre a fonte escrita consultada e a variedade linguística falada na região" que, no caso em foco, pode ser a variedade mineira.

Essas fontes geralmente apresentam data, origem, autoria, condições essas que proporcionam certo conforto ao estudioso para determinar alguns aspectos linguísticos do estágio no qual se encontrava a língua à época em que o documento fora produzido. (...)

(CONDÉ, 2009, p. 235) 


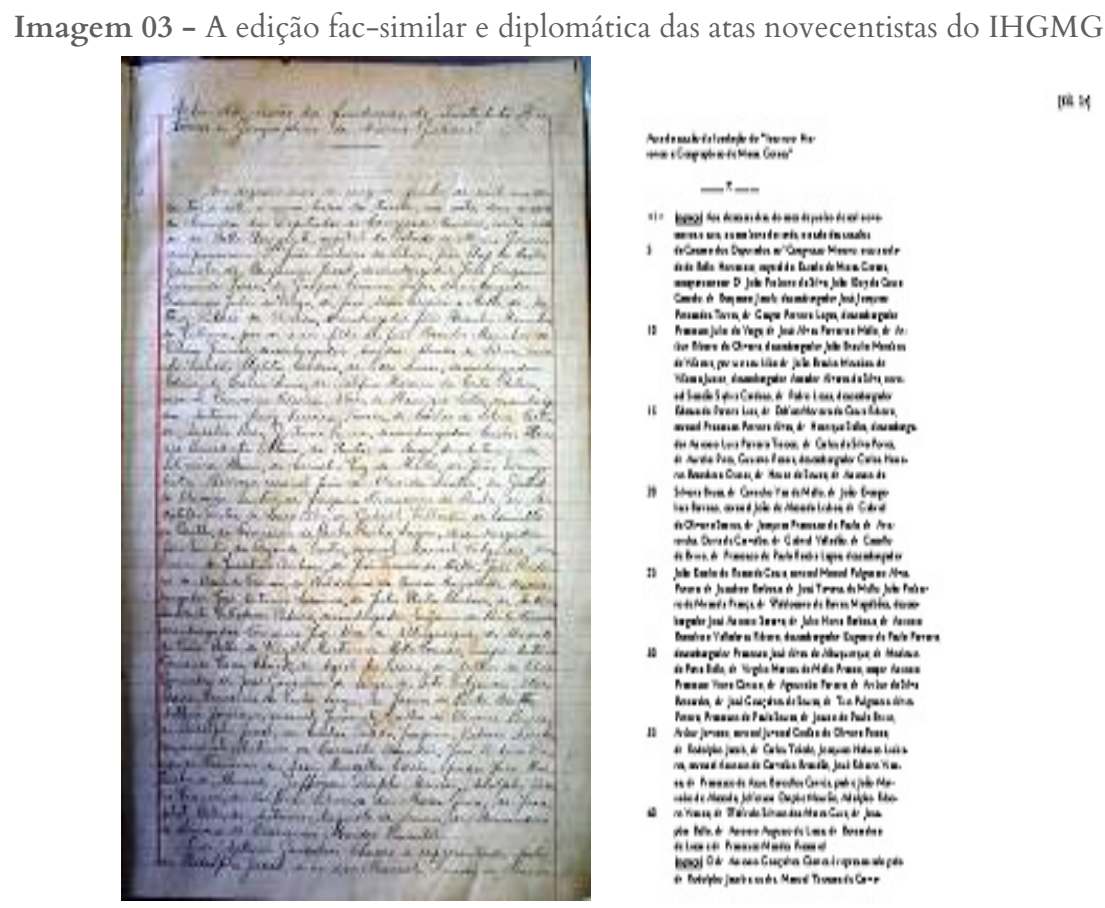

As trinta e oito (38) atas editadas por Silva (2016) estão estruturadas em setenta e dois (72) fólios expressos, por sua vez, em trinta e seis (36) fólios (recto e verso) sequencialmente numerados. Em tão somente três (03) delas, observamos tratar-se de amostras autógrafas, ou seja, redigidas e assinadas por Francisco Mendes Pimentel (entre os fólios 1r-3v) e por Juscelino Barbosa (entre os fólios 4r-5v, fólios $7 \mathrm{r}-7 \mathrm{v}$ ), respectivamente, em 1907. Para as demais trinta e cinco (35) atas, temos, em vinte delas (20), o punho de Luiz Pessanha, secretário suplente responsável pela redação das tais vinte atas (20), que, por sua vez, foram assinadas pelo respectivo Presidente da sessão (atas originais não-autógrafas): entre os fólios 5v-6v e 8r-17r. Entre os fólios 7v e 8r, temos uma ata redigida por Juscelino Barbosa e assinada pelo presidente da sessão (João Pinheiro da Silva), o que permite interpretá-la também como uma ata original não-autógrafa. As demais quatorze (14) atas foram redigidas por um punho não identificado (entre os fólios 17v-36r), ainda que a escritura de tais atas tenha sido atribuída ao Secretário Luiz Pessanha. Na sequência, passamos à descrição paleográfica dos punhos dos escreventes das atas do IHGMG, cf. a análise de Silva (2016).

O trabalho do crítico textual está fundamentado também em conhecimentos paleográficos, tendo em vista que o seu objetivo principal é o de reconstituir a configuração da prática de escrita de sincronias passadas. Nesse sentido, destacamos a relevância da proficiência do crítico textual em relação à decodificação do código escrito no manuscrito original. Considerando a pertinência da paleografia como um auxílio ao trabalho na área da crítica textual, passamos em conformidade com Berwanger e Franklin Leal ([1995] 2008, p. 107) à uma sucinta descrição de aspectos paleográficos tais como a morfologia das letras, o seu traçado (ductus), ângulo, módulo e o peso do traçado. Além disso, descrevemos, à luz de Silva (2016), traços que se mostram relevantes à caracterização paleográfica dos 
punhos dos escreventes (Francisco Mendes Pimentel, Juscelino Barbosa, Luiz Pessanha e um punho não identificado).

As trinta e oito atas novecentistas (1907-1916) do IHGMG editadas por Silva (2016) evidenciam a letra cursiva como "traçadas de um só lance e sem descanso de mão", cf. Acioli (1994, p. 13). De um modo geral, é possível interpretarmos as mãos que redigiram as atas como hábeis, cf. Marquilhas (2000), devido, principalmente, à leveza, à legibilidade do traçado da escrita e à homogeneidade do cursus. Os apontamentos paleográficos estão encaminhados em relação à análise da morfologia das letras, do seu traçado, ângulo, módulo e peso específicos dos punhos dos secretários que efetivamente lavraram as atas cujo estado de conservação é excelente.

No que se refere à morfologia das letras e ao ductus, observamos que, de uma forma geral, as letras dos escreventes mostram-se distintas entre si em relação ao traçado, mas pequenas em relação à sua forma (morfologia) cujos traçados (ductus) estão levemente inclinados para a direita (com graus variáveis de inclinação, já que para a escrita de Mendes Pimentel o grau de inclinação para a direita é mínimo, restrinta a grafemas específicos como "p", "l" e "t"), cf. observamos nas imagens de (04) a (06) em que estão ilustrados os punhos de Francisco Mendes Pimentel, Juscelino Barbosa e Luiz Pessanha, respectivamente.

Imagem 04 - Punho de Francisco Mendes Pimentel (15.06.1907, fól. 2v:165).

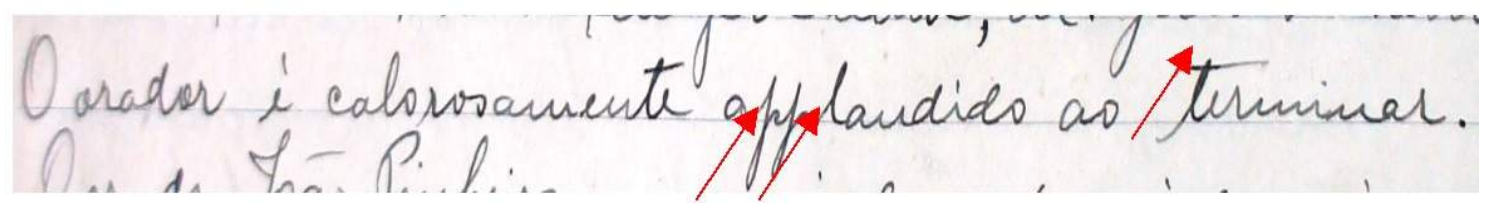

“O orador é calorosamente applaudido ao terminar." (15.06.1907, fól. 2v:165)

Imagem 05 - Punho de Juscelino Barbosa (12.07.1907, fól. 4r:269).

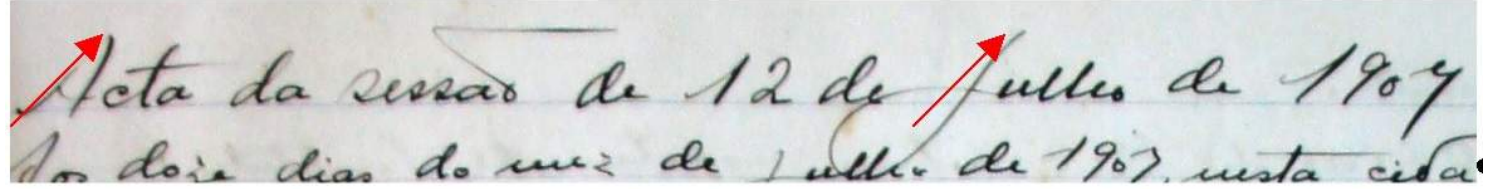

“Acta da sessão de 12 de Julho de 1907” (12.07.1907, fól. 4r:269) 
Imagem 06 - Punho de Luiz Pessanha (16.11.1907, fól. 8r:663).

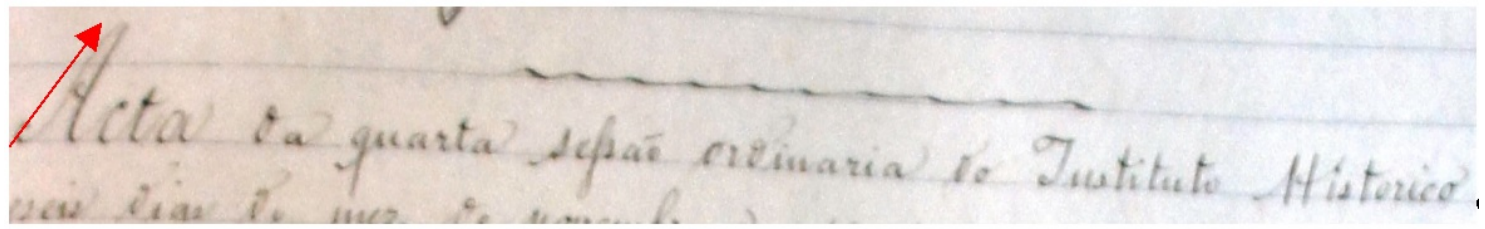

“Acta da quarta sessão ordinaria do Instituto Historico” (16.11.1907, fól. 8r:663)

Passamos à análise do ângulo, do módulo e do peso, respectivamente, caracterizados pela relação entre os traços verticais e a horizontalidade da pauta, a dimensão das letras e a relação entre os segmentos finos e grossos dos grafemas específicos das produções escritas de Francisco Mendes Pimentel, Juscelino Barbosa e Luiz Pessanha cujos punhos estão descritos a seguir.

$\mathrm{Na}$ única ata redigida e assinada por Mendes Pimentel ("Acta da sessão da fundação do "Instituto Historico e Geographico de Minas Geraes”, em 1907”), a sua letra cuja dimensão é pequena (módulo), apresenta, de modo geral, traços finos, que somente se mostram mais grossos (peso) como estratégia de correção numa espécie de leve rasura como observamos nos grafemas "a" da sílaba final da palavra "fachada" e "l" da palavra "Ultramarino", cf. imagem (07).

Imagem 07 - Punho de Francisco Mendes Pimentel (15.06.1907, fól. 2r:130-132).

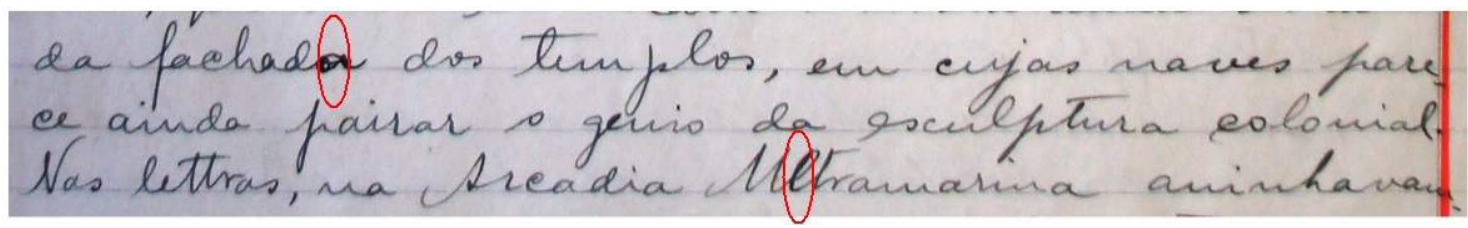

130 da fachada dos templos, em cujas naves parece ainda pairar o genio da esculptura colonial. Nas lettras, na Arcadia Ultramarina aninhavam-

Na escrita de Francisco Mendes Pimentel, identificamos, em relação ao ângulo, que os traços verticais de algumas letras minúsculas, de um modo geral, ultrapassam moderadamente o limite entre as linhas da pauta, conforme evidenciamos em (7a), como já era previsto em relação à morfologia das letras dos grafemas cujas hastes são descendentes tais como "p", "j” e "g”. Alguns grafemas maiúsculos cujos traços verticais tendem a ultrapassar a linha ainda se mantêm no limite entre as duas linhas (inferior e superior), como observamos em (7b) em relação aos grafemas maiúsculos "R", "J", "A" e "G". 

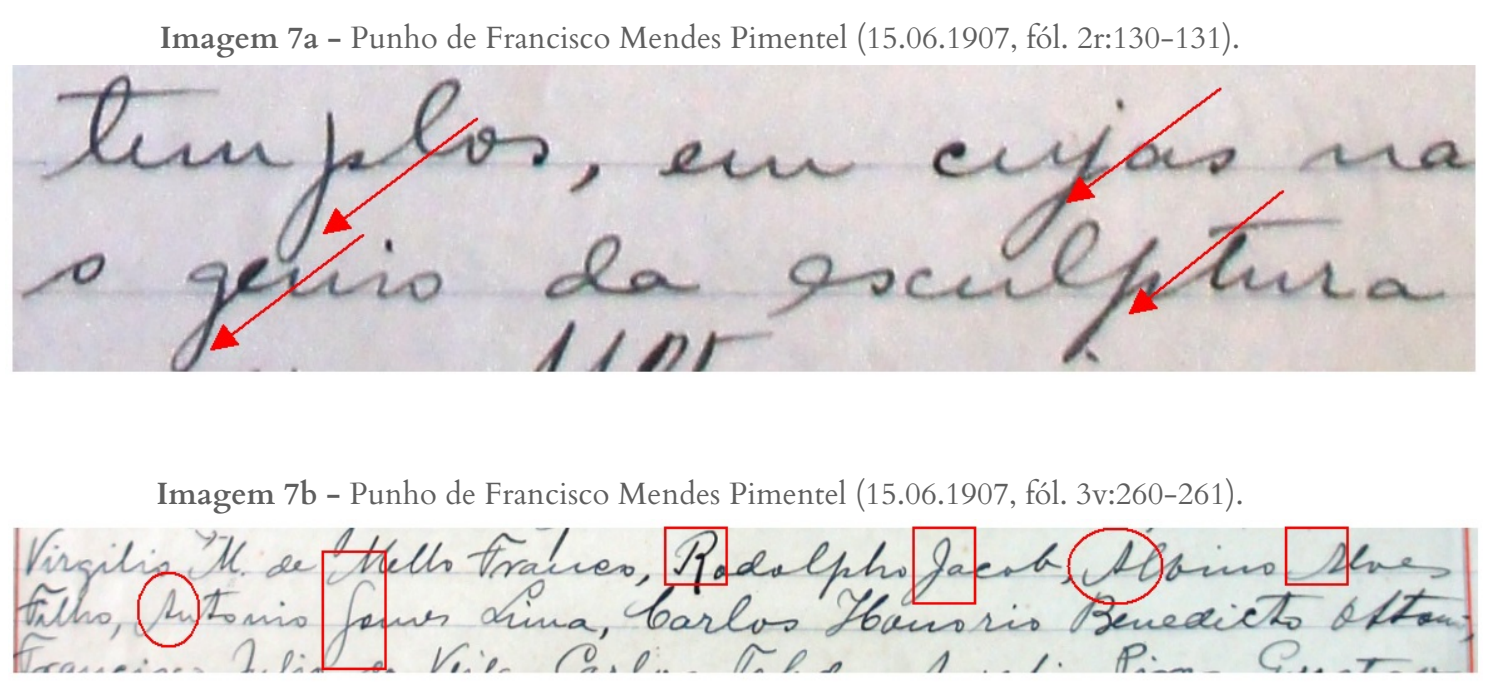

Na produção escrita de Juscelino Barbosa, verificamos, em relação à dimensão dos grafemas no interior da pauta, letras de dimensão pequena (módulo) potencialmente estruturadas com traços finos, mas firmes e bem visíveis (peso), cf. ilustramos em (08).

Imagem 08 - Punho de Juscelino Barbosa (14.09.1907, fól. 7r:547-554).

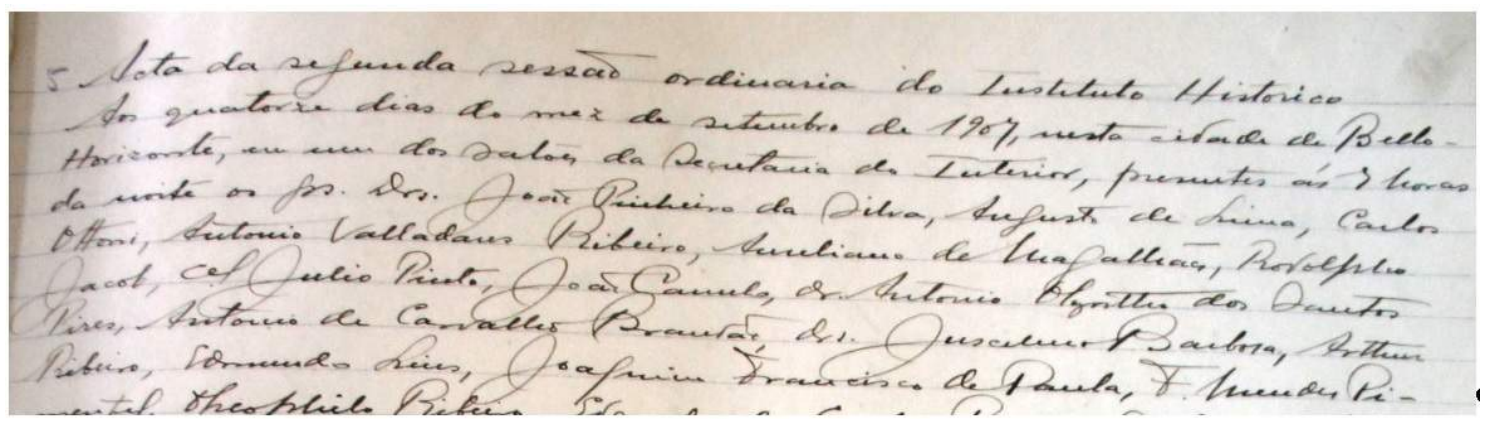

<5> Acta da segunda sessão ordinaria do Instituto Historico

Aos quatorze dias do mez de setembro de 1907, nesta cidade de Bello-

Horizonte, em um dos salões da Secretaria do Interior, presentes ás 7 horas

550 da noite os Srs. Drs. João Pinheiro da Silva, Augusto de Lima, Carlos Ottoni, Antonio Valladares Ribeiro, Aureliano deMagalhães, Rodolpho

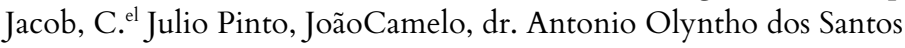
Pires, Antonio de CarvalhoBrandão, drs. JuscelinoBarbosa, Arttur Ribeiro, Edmundo Lins, Joaquim Francisco dePaula, F. Mendes Pi-

Verificamos que as letras minúsculas mantêm-se, em geral, com seus traços verticais no limite entre as linhas da pauta, ao passo que as letras maiúsculas espraiam-se um pouco mais pelos limites superior e inferior da linha da pauta (ângulo), mantendo-se potencialmente inclinadas para a direita, como ilustramos em (8a), para a letra "g", ainda que os traços mostrem-se lineares. Já em (8b), 
observamos os grafemas maiúsculos "J" e "G" cujas hastes descendentes ultrapassam bem mais o limite entre as linhas da pauta.
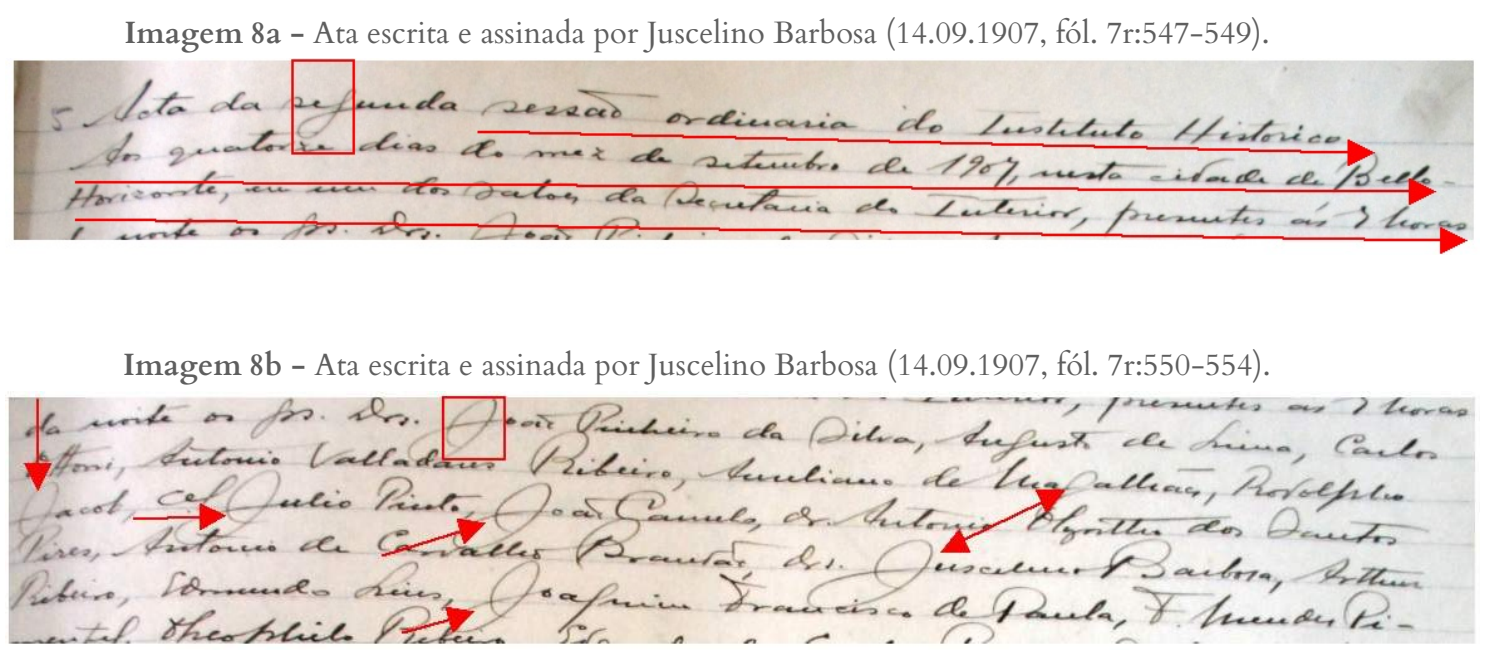

A assinatura de Juscelino Barbosa pode ser legitimamente confirmada, ao ser confrontada com a sua assinatura em uma carta familiar (pertencente ao Arquivo Público Mineiro doravante APM), dirigida ao seu filho, conforme verificamos em (8c) e (8d), respectivamente.

Imagem 8c - ${ }^{9}$ Punho de JB, Ata [fól. 5v:430]. Imagem 8d - ${ }^{10}$ Punho de JB, Carta familiar, 13.11.1933.
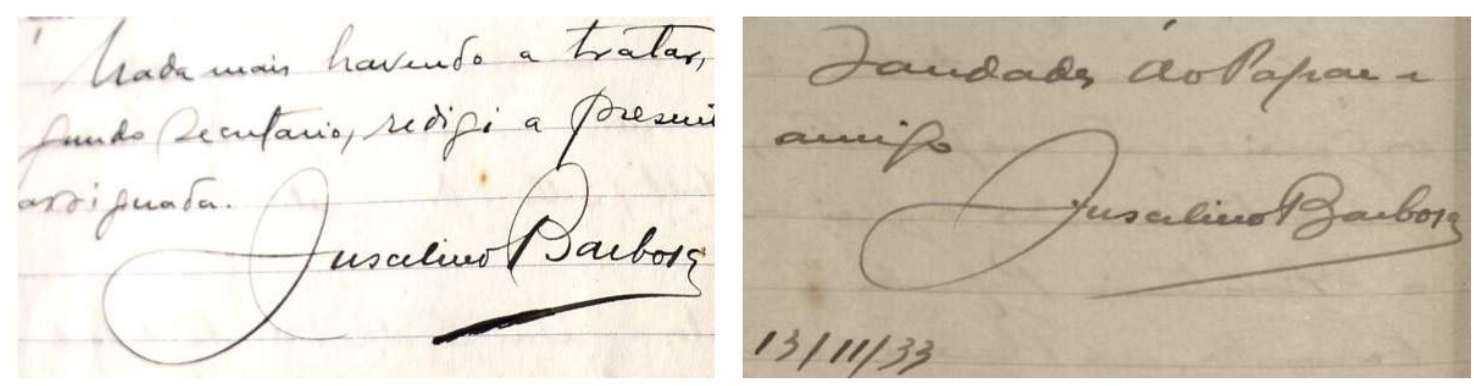

A produção escrita de Luiz Pessanha é marcada por traços leves (peso) inclinados para a direita. De um modo geral, a sua escrita mostra-se legível, marcada por traços pequenos em relação à pauta (módulo) devido à espessura diminuta do traçado da sua letra em relação à pauta. As letras minúsculas e as maiúsculas de Luiz Pessanha apresentam-se prioritariamente entre os limites das linhas superior e inferior da pauta (ângulo), ainda que as letras minúsculas “j”, "g”, "p”, “q”, "l” cujas hastes constituam mesmo em essência como descendentes tendam a ultrapassar a linha da pauta, como observamos em (9a) e (9b).

\footnotetext{
${ }^{9}$ Fonte: IHGMG.

${ }^{10}$ Fonte: APM.
} 
Imagem 09 - Punho de Luiz Pessanha (31.12.1911, fól. 16r:1381-1385).

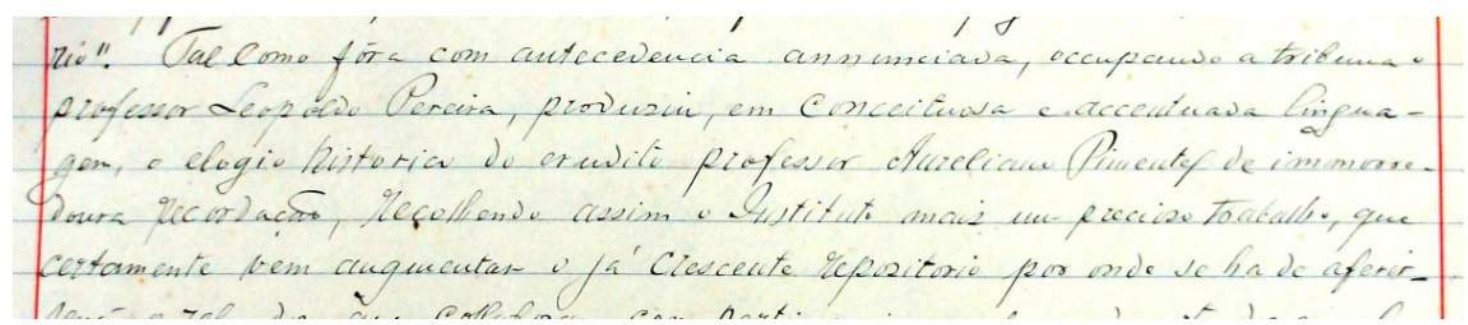

rio". Tal como fóra com antecedencia annunciada, occupando a tribuna o professor Leopoldo Pereira, produziu, em conceituada e accentuada linguagem o elogio historico do erudito professor Aureliano Pimentel de immorredoura recordação, recolhendo assim o Instituto mais em preciso trabalho, que certamente vem augmentar o já crescente repositorio por onde se ha de aferir _

Imagem 9a - Punho de Luiz Pessanha (31.12.1911, fól. 16r:1385).

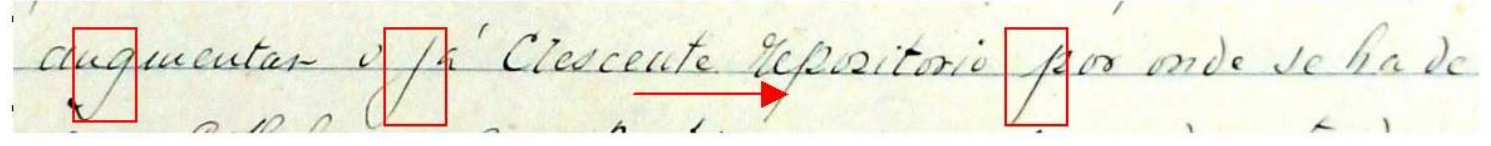

Imagem 9b - Punho de Luiz Pessanha (31.12.1911, fól. 16r: 1383).

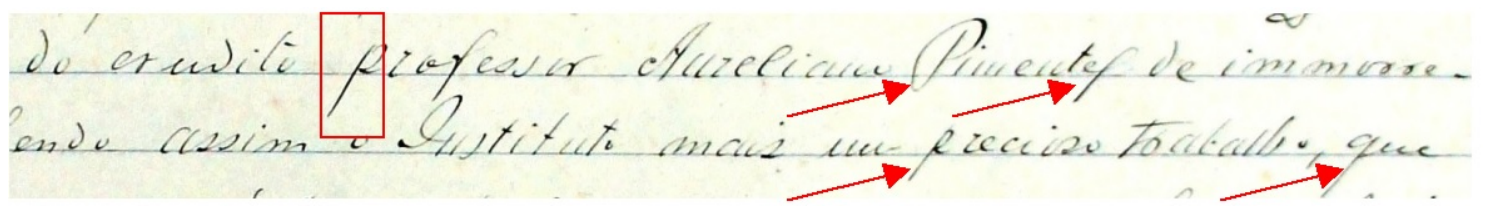

Entre os fólios 17v e 36r, temos em análise um punho distinto dos punhos de Mendes Pimentel, Juscelino Barbosa e Luiz Pessanha. No intervalo entre os fólios 17v e 36r, o traçado de escritura das atas também mostrou-se bem diferente do punho de Luiz Pessanha, ainda que, nestas, Luiz Pessanha seja mencionado como Secretário tanto em construções sintáticas ativas com o verbo "lavrar" na forma verbal "lavrei eu" (sujeito de $1^{\text {a }}$ pessoa do singular), cf. imagem 11, quanto em construção passiva analítica ("ata por mim assignada”), cf. imagem 12, antecedida por passiva sintética pronominal com "se" indeterminador ("Para constar lavrou-se a ata que I vai por mim assignada."). Interessante é identificarmos que parece prevalecer, nas atas redigidas e assinadas pelo punho de Luiz Pessanha, a referência pronominal explícita ao sujeito de $1^{a}$ pessoa do singular ("mim" e "eu"), o que parece constituir mesmo uma forma de o autor responsabilizar-se pela escrituração de toda a ata em questão. Por outro lado, nas atas lavradas por um punho não identificado (cf. imagem 10), observamos a passiva sintética ("e para constar lavrou-se a presente acta. I OSecretario, Luis Pessanha") que acaba por semanticamente indeterminar o sujeito agente de redação de tais atas, ainda que o sujeito sintático (gramatical) seja mesmo o sintagma nominal "a presente acta”, cf. exemplificamos em (10). Em relação às estruturas passivas analíticas, verificamos que foram comprovadamente lavradas mesmo pelo 
Secretário Luiz Pessanha entre os fólios 5v-6v e 8r-17r (cf. imagens 11 e 12) cujo traçado da letra é menor, bem mais fino e inclinado para a direita do que o traçado não identificado em questão entre os fólios $17 \mathrm{v}$ e $36 \mathrm{r}$, cf. identificamos em (10).

Imagem 10 - Punho não identificado (24.03.1914, fól. 32r:2861-2864).

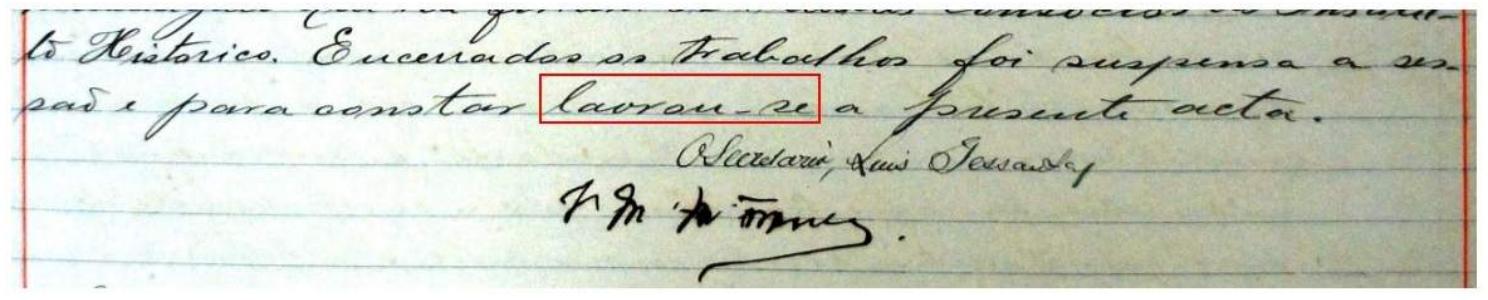

2860 homenagem que lhe $<\uparrow$ con $>$ feriam os illustres consocios do Institu-

to Historico. Encerrados os trabalhos foi suspensa a ses-

são e para constar lavrou-se a presente acta.

${ }^{11}$ OSecretario, Luis Pessanha

V. M. M. Franco.

Imagem 11 - Ata escrita e assinada por Luiz Pessanha (27.08.1911, fól. 14r: 1226-1229).

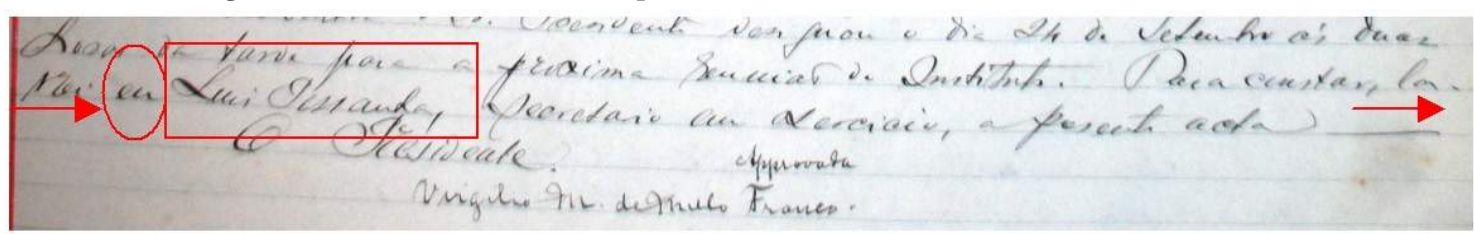

1225 cerrados os trabalhos o Sr. Presidente designou o dia 24 de Setembro ás duas

horas da tarde para a proxima reunião do Instituto. Para constar, la-

vrei eu Luis Pessanha Secretario em exercicio, apresente acta

O Presidente.

${ }^{12}$ Approvada

Virgilio M. deMello Franco.

Imagem 12 - Ata escrita e assinada por Luiz Pessanha (14.05.1911, fól. 12r: 1031-1033).

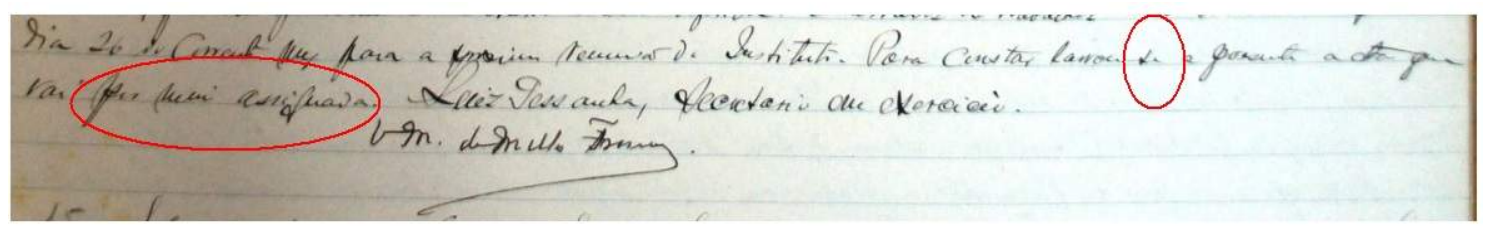

\footnotetext{
${ }^{11}$ Nota de rodapé produzida por Silva (2016, p. 185) em seu trabalho de edição das atas do IHGMG. "O trecho "O Secretario, Luis Pessanha” foi realmente redigido por Luiz Pessanha, mas tal punho é diferente do punho que efetivamente redigiu a ata que, por sua vez, também é bem diferente do punho de quem a assinou: "V. M. M. Franco".

${ }^{12}$ Nota de rodapé produzida por Silva (2016, p. 113): "A aprovação da ata se deu através da inscrição "Approvada" produzida pelo Presidente da sessão Virgilio M. de Mello Franco que, por sua vez, não redigiu toda a ata, sendo esta escrita pelo Secretário Luiz Pessanha."
} 
1030 de Minas, pelo seu presidente eSecretario acima referidos. Encerrados os trabalhos o Sr. Presidente designou o

dia 26 do Corrente Mes para a proxima reunião do Instituto. Para constar, lavrou-se a presente acta que

vai por mim assignada. Luiz Pessanha, Secretario em Exercicio.

VM. deMello Franco.

Assim sendo, o argumento sintático parece corroborar o argumento paleográfico de que as atas produzidas entre os fólios 17v e 36r não foram mesmo integralmente redigidas pelo Secretário Luiz Pessanha, ainda que este tenha sido responsabilizado por lavrá-las.

Confrontamos, na sequência, os traçados das assinaturas de Luiz Pessanha nas atas redigidas pelo seu próprio punho e em ata lavrada pelo punho de tal Secretário, cf. apresentamos em (13) e (14), respectivamente. Observamos, em (13), uma ata original não-autógrafa caracterizada pelo fato de o punho de escritura da ata ser visivelmente diferente do punho a quem se atribui o secretariado da sessão (Luiz Pessanha). Por outro lado, em (14), o punho de quem redigiu a ata é idêntico ao punho de quem se responsabilizou por tê-la lavrado, ainda que ambas as atas tenham sido assinadas por uma outra personalidade (Virgílio Martins de Melo Franco) que é quem geralmente responsabiliza-se pela Presidência da sessão.

Passamos à análise paleográfica do punho cuja identificação social não foi possível levantar. No que se refere à morfologia das letras e ao ductus do punho não identificado, verificamos que a sua forma é arredondada em sua expressão cursiva cujo traçado é marcadamente inclinado para a direita. Em relação aos traços verticais das letras e a pauta horizontal, constatamos que o ângulo das letras maiúsculas e minúsculas inclinadas para a direita mantiveram-se no limite entre as linhas da pauta, cf. ilustramos em (13), ainda que para as letras cujas hastes sejam descendentes em essência, "p", "J", "f", "q", "g" e "z", estas tenderam a ultrapassar, bem timidamente, o limite entre as linhas da pauta, assim como também observado em relação ao grafema minúsculo "x".

Imagem 13 - Punho não identificado (25.07.1915, fól. 35r:3139-3145).

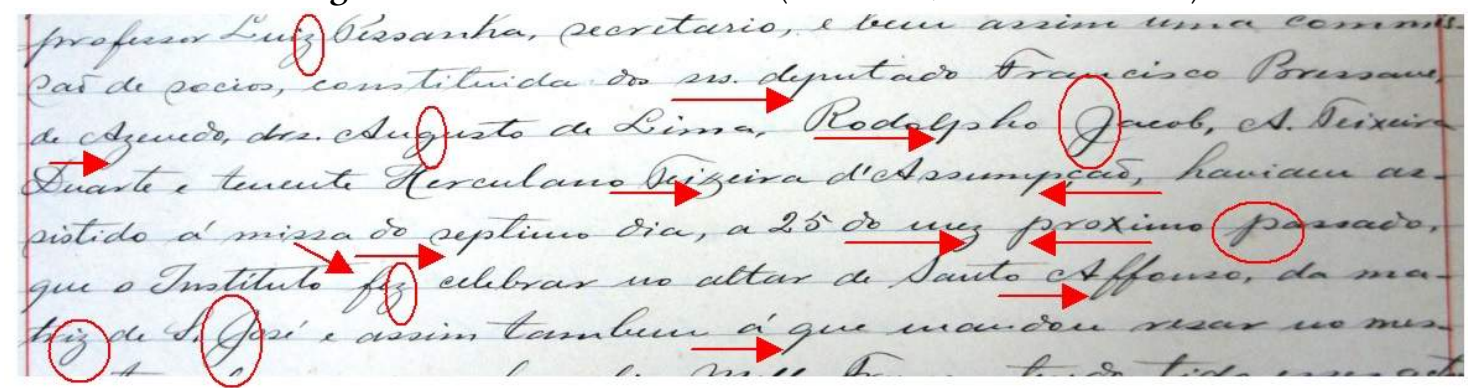

professor Luiz Pessanha, secretario, e bem assim uma commis-

3140 são de socios, constituida dos srs. deputados Francisco Bressane de Azevedo, drs. Augusto de Lima, Rodolpho Jacob, A. Teixeira Duarte e tenente Herculano Teixeira d'Assumpção, haviam assistido á missa do septimo dia, a 25 do mez proximo passado, que o Instituto fez celebrar no altar de Santo Affonso, da matriz de S. José e assim tambem á que mandou resar no mes- 
A dimensão das letras em relação à pauta se manteve pequena (módulo) cujo peso mostrou-se predominantemente com traços finos, como evidenciamos em (13) e (14).

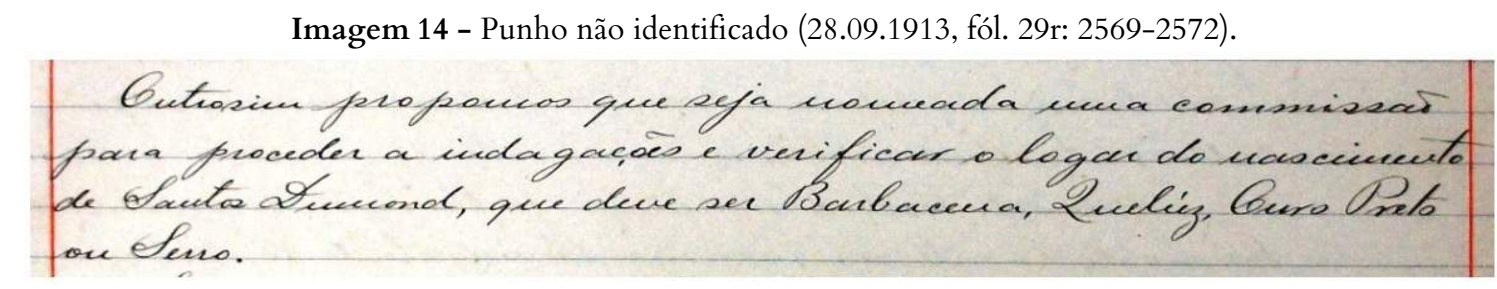

[espaço] Outrosim propomos que seja nomeada uma commissão 2570 para proceder a indagações e verificar o logar do nascimento de Santos Dumond, que deve ser Barbacena, Quelúz, Ouro Preto ou Serro.

Considerando que a conservadora edição das atas novecentistas proposta por Silva (2016) serve de base para as futuras análises linguísticas acerca da expressão da escrita culta do PB, no espaço geográfico mineiro do início do século XX (1907-1916), assumimos a necessidade de identificação, do ponto de vista paleográfico, dos punhos responsáveis pela redação das atas do IHGMG, o que foi confrontado com o perfil social dos escreventes reconstruídos com base na análise de fontes históricas (artigos em revistas periódicas (Mendes Pimentel), instrumentos de pesquisa do APM (Juscelino Barbosa), publicações em livro (LASMAR, 2015) e publicação periódica ${ }^{13}$ (Luiz Pessanha). Constatamos, à luz de um estudo paleográfico (análise do traçado (ductus), ângulo, módulo e peso das letras) em conformidade com Berwanger e Franklin Leal ([1995] 2008), quatro punhos responsáveis pela redação das atas do IHGMG. São eles: Francisco Mendes Pimentel, Juscelino Barbosa, Luiz Pessanha e um punho socialmente não identificado. Silva (2016) reconstruiu plenamente os perfis biográficos dos escreventes Francisco Mendes Pimentel ${ }^{14}$ e Juscelino Barbosa ${ }^{15}$, ao passo que o Secretário que mais

\footnotetext{
${ }^{13}$ Publicação em Periódico intitulado "MINAS GERAIS: orgão official do governo do estado" produzido em Ouro Preto, 12 de novembro de 1893 no qual se faz menção ao Professor Luiz Gonçalves da Silva Pessanha.

${ }^{14}$ FRANCISCO MENDES PIMENTEL: Informante nascido no Rio de Janeiro, a 21 de Janeiro de 1869 e falecido no Rio de Janeiro, a 30 de Agosto de 1957. Trata-se de um "Político, advogado, professor e primeiro reitor da Universidade Federal de Minas Gerais (UFMG). Foi deputado estadual (1895-1898) e deputado federal (1897-1899). Atuou também na imprensa, fundando o Diário de Minas. Participou da fundação do Instituto Histórico e Geográfico de Minas Gerais (IHGMG). Foi um dos fundadores do PRM (Partido Republicano Mineiro)", cf. Silva (2007, p. 88).

${ }^{15}$ JUSCELINO BARBOSA: Informante nascido em Santa Cruz da Chapada, Distrito de Minas Novas, MG, a 13 de junho de 1875. Foi Deputado estadual, Promotor de Justiça, Comandante Geral da Brigada Policial de Minas Gerais, Prefeito de Poços de Caldas, Secretário das Finanças do Estado, Diretor da Rede Sul Mineira de Viação, Professor da Faculdade Livre de Direito de Minas Gerais; Fundador do Banco Hipotecário e Agrícola Riacho Fundo e do Jornal Estado de Minas, cf. Inventário da Coleção Família Juscelino Barbosa (2005).
} 
redigiu atas dentre as editadas, Luiz Pessanha ${ }^{16}$, teve o seu perfil social parcialmente reconstruído. Verificamos tratar-se de um escrevente culto, um Professor de Língua Portuguesa e Literatura Brasileira atuante em Ouro Preto, o que justifica a edição das atas do IHGMG como uma representativa amostra da expressão escrita do PB culto novecentista.

Acreditamos, em suma, que as trinta e oito atas do IHGMG são evidências de produções textuais legitimamente brasileiras cujas validade histórica e social são irrefutáveis, tendo em vista não só a identificação da autoria dos textos, mas também de tais atas evidenciarem o modo como representantes da intelectualidade mineira se organizavam, no início do século XX, para pensar questões da História e da Geografia brasileiras.

\section{A edição das receitas culinárias novecentistas}

Trazemos à cena as edições fac-similares e diplomáticas de receitas culinárias novecentistas produzidas por Martins (2017) e Santos (2018). Trata-se de dois pequenos códices encadernados compostos por cinquenta e um (51) e oitenta e nove (89) fólios opistógrafos de receitas culinárias resguardadas no interior do Acervo de Escritores Mineiros (doravante AEM) no âmbito da Biblioteca Central da UFMG. Nos códices em análise, há menções não só à data (22 de agosto de 1905), mas também ao local (Ouro Preto, para o códice de 21 de julho de 1906). Além dessas menções ao local (códice de 1906) e à data (em ambos os códices), cf. as imagens 15 e 16, observamos a referência a dois antropônimos (códice de 1906), ${ }^{17}$ possivelmente relacionados a integrantes de famílias mineiras, já que tal conjunto de receitas culinárias encontra-se envolvido sob o rótulo de "receitas de vovós mineiras".

\footnotetext{
${ }^{16}$ LUIZ PESSANHA: "Professor de Portuguez e Litteratura Nacional da Escola Normal de Ouro Preto, Secretário do Interior", cf. Pessanha et al. (1913, p. 267) e também cf. a publicação periódica "MINAS GERAIS: orgão official do governo do estado” datada de Ouro Preto, 12 de novembro de 1893, cf. Silva (2016, p. 26).

${ }^{17}$ Neste texto, optamos por resguardar as identidades das pessoas envolvidas, referenciando os antropônimos mencionados nas receitas culinárias a partir das suas letras iniciais (Dona B. M. e A.), cf. observamos na imagem 16.
} 
Imagem 15 - Fac-símile do fólio 12v, cf. Martins (2017, p. 13)
Imagem 16 - Fac-símile da "Folha de rosto" do caderno de receitas novecentistas, cf. Santos (2018, p. 15).
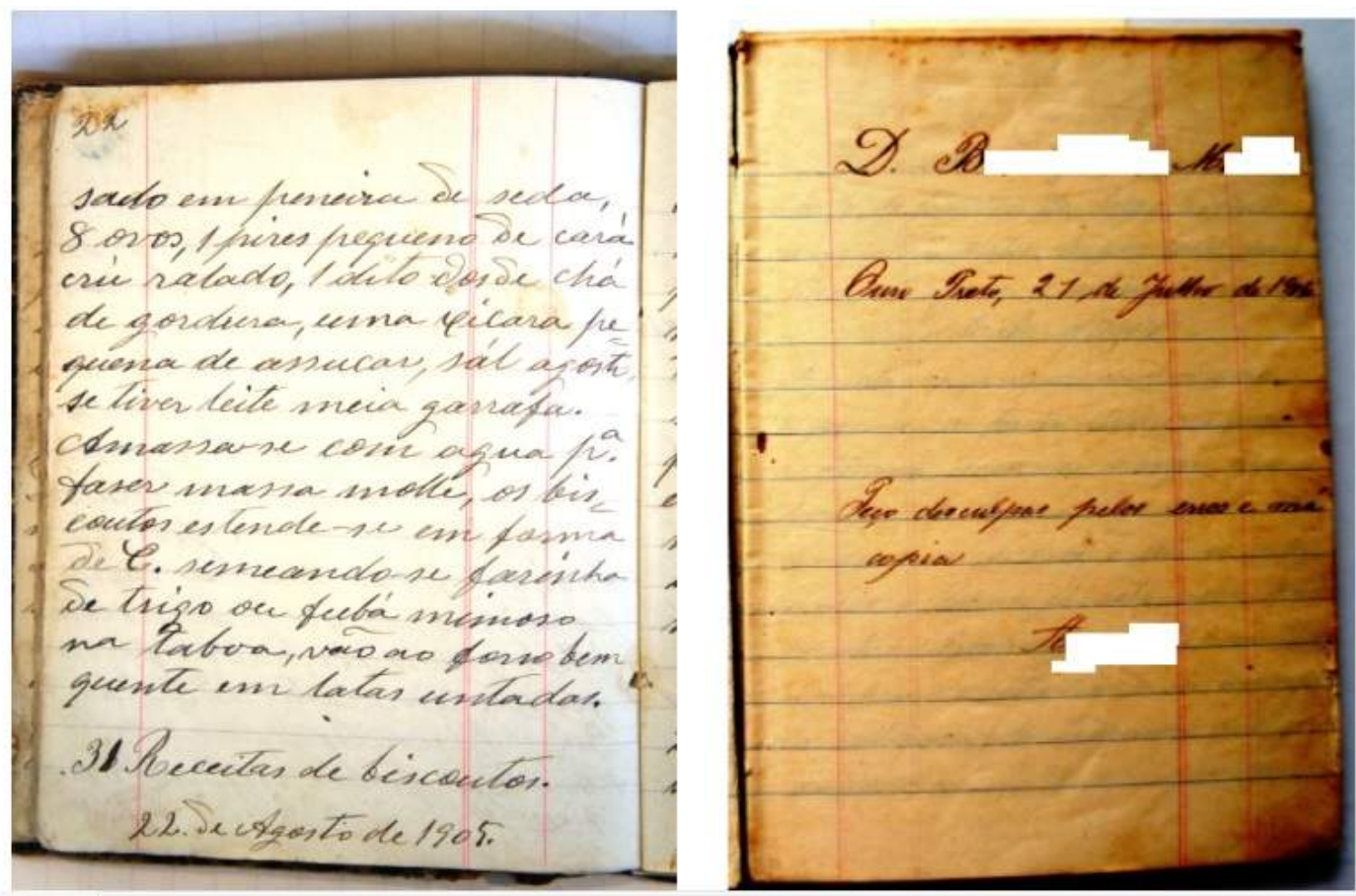

A preferência pela edição fac-similar e diplomática foi motivada, em consonânia com Spina (1977), Vasconcellos e Santiago-Almeida (2012), Santiago-Almeida (2009), Carvalho e Silva (1994), pelo intuito de trazer, conservadoramente, à comunidade linguística, relevantes textos manuscritos em realidades pretéritas do $\mathrm{PB}$, de modo a evidenciá-los também como amostras para futuras pesquisas linguísticas. Optamos por uma conservadora edição das receitas culinárias novecentistas, mantendo, assim, a grafia, a delimitação vocabular (imagem 17), a pontuação e qualquer outra evidência prática linguístico-textual do século XX merecedora de comentários em formato de nota de rodapé (imagem 18).

Imagem 17 - O respeito à delimitação de palavras, cf. Martins (2017, p. 17).

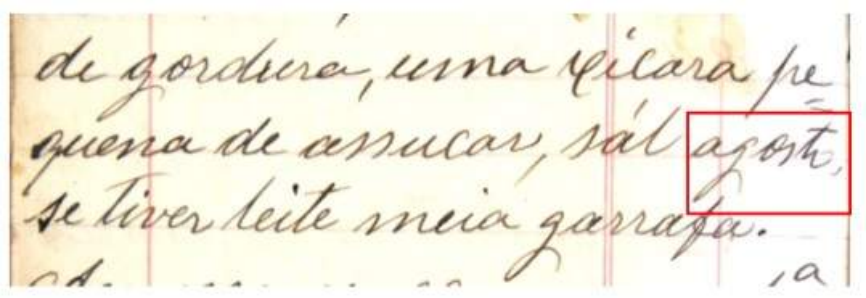

de gordura, uma xícara pe $=$ quena de assucar, sál agosto, se tiver leite meia garrafa.

$[$ fól. 9v] 


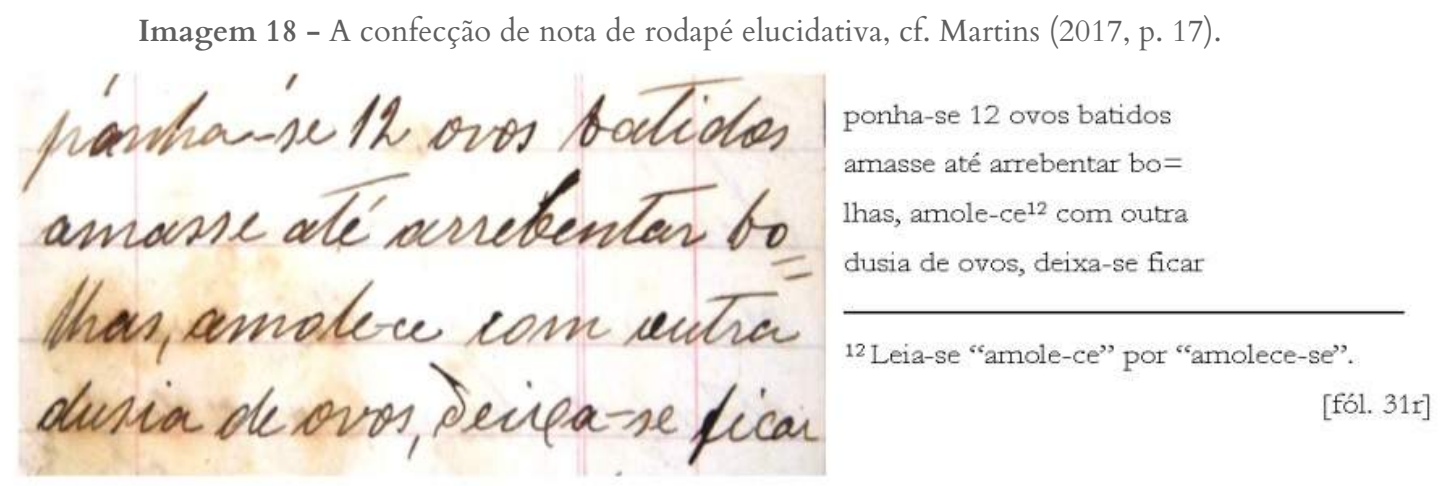

Em relação aos tópicos para futuras análises linguísticas, observamos as construções com o se (CAVALCANTE, 2016) nas receitas culinárias de 1906. Verificamos, de (01) a (06), algumas evidências da expressão variável das estruturas sintáticas com o se, seja com o se indeterminador, seja com o se apassivador, projetadas pelos mesmos predicadores verbais ("bater", "ajuntar", "por", "fazer”, "formar"), cf. discutido por Martins (2017) e por Santos (2018).

(01) "bate-se [...] 15 gemmas" [fól. 23v] e "batem-se 10 gemmas" [fól. 35v];

(02) "batem-se 1 duzia de óvos" [fól. 29r] e "bate-se 1 duzia de óvos" [fól. 23r];

(03) “ajunta-se-lhe 3 duzias" [fól. 21r] e “ajuntem-se 1 libra de assucar” [fól. 29v];

(04) “põe-se no forno os biscoutos" [fól. 24r] e "poem-se os ovos" [fól. 12r];

(05) "faz-se os biscoutos" [fólios 13r, 18v, 19r, 20r, 21v) e "fazem-se os biscoutos" [fól. $25 \mathrm{r}]$;

(06) “formem-se os biscoutos" [fól. 24r] e "forma-se os biscoutos" [fól. 26r].

De um modo geral, entendemos que, ao editarmos os manuscritos novecentistas de maneira a mantê-los fieis aos seus fac-símiles, permitimos que o linguista-pesquisador não só identifique traços paleográficos, mas também desvele aspectos linguísticos da norma de uso do PB escrito no início do século XX. Ainda que em relação às receitas culinárias novecentistas não tenha sido possível comprovar a sua autoria mineira (já que se trata de um conjunto de receitas culinárias que está sob o rótulo de "receitas de vovós mineiras" no interior do AEM), é possível entender tais receitas culinárias como legítimas fontes para o estudo do português em sua expressão escrita no século XX. 


\section{A edição das cartas pessoais oitocentistas e novecentistas}

Idas constantes aos acervos públicos em Belo Horizonte foram-nos uma grata surpresa, considerando o levantamento de um conjunto de cerca de quatrocentos e setenta e duas missivas pessoais (472) produzidas no período de 1860 e 1989 e diversificadamente organizadas em amizade, amor e familiares. Dentre as nossas visitas aos acervos, passamos pelo AEM, IHGMG, Arquivo Público da Cidade de Belo Horizonte (doravante APCBH) e Museu Abílio Barreto (doravante MAB) para os quais daremos notícias não só sobre a qualidade do material levantado, mas também sobre os encaminhamentos metodológicos para o levantamento e a edição dessas amostras históricas. Como a maioria das cartas foi produzida por ilustres escreventes mineiros foi-nos possível o resgate da história de vida desses informantes e, até certo ponto, também de seus familiares e amigos. Para tal, valemonos não só de índices genealógicos (BUENO; BARATA, 2001) e dicionários biográficos (MARTINS FILHO, 2013), mas também dos instrumentos de pesquisa de que dispomos no interior dos próprios acervos. Como esse trabalho de composição de corpora confiáveis passa, nos moldes de Lobo (2001) e Rumeu (2013), pela reconstituição da história de vida dos informantes (missivistas), justificamos também o controle das díades que sustentam a dinâmica das cartas pessoais em suas dinâmicas de amizade, de amor e familiares. Optamos, também em relação às cartas pessoais, pela conservadora edição de tais missivas históricas, o que consiste na sua exposição através do fac-símile sempre ao lado da sua transcrição ipsis litteris. Isso significa dizer que nessa proposta de edição conservadora preferimos não fazer modernizações em relação à aspecto linguístico algum, mantendo-nos fieis à grafia, acentuação e sintaxe das construções específicas das sincronias passadas em foco (séculos XIX e $\mathrm{XX)}$.

Partimos, inicialmente, do AEM, de onde levantamos trezentas e cinquenta e sete (357) cartas que embasaram as monografias de Figueiredo (2013) e de França (2016) sobre a dinâmica tu/você em distintos estágios de composição das amostras de cartas pessoais mineiras, a monografia de Costa (2014) acerca da ordem dos clíticos em complexos verbais e as dissertações de mestrado de Cruz (2017) e de Cardoso (2017) acerca da alternância tu/você nos contextos sintáticos de complementação e de adjunção e das estruturas dativas de 2SG, respectivamente. Ainda que, no AEM, prevaleçam as missivas mineiras, é possível encontrarmos missivas de autores cariocas (Cecília Meireles, Marques Rebelo, Stella Leonardos), o que motivou Diniz (2018) a usá-las como amostras textuais que embasaram a sua discussão sobre a expressão variável do imperativo de 2SG em cartas cariocas (séculos XIX e $\mathrm{XX}$ ). Nesse acervo, destacamos ainda as cartas mineiras trocadas entre importantes autores da 
literatura brasileira entre si (cartas de amizade), entre familiares e entre noivos e namorados. ${ }^{18} \mathrm{Em}$ relação ao acervo do IHGMG, identificamos, até o momento, por volta de sessenta e quatro (64) cartas. Trata-se de cartas produzidas no decorrer do século XX cujo tom de intimidade é acentuado pela temática das cartas (missivas direcionadas ao Pe. Agenor por seu pai, irmã, primos, tios e cunhado versando sobre saudades, notícias várias e solicitações) sempre em torno de questões de uma família mineira (Alves Pinto). No APCBH, encontramos a coleção Nelson Coelho de Senna composta por trinta e cinco (35) missivas, igualmente familiares, ${ }^{19}$ produzidas, de um modo geral, por seus pais, filhos, irmãos, tios e primos em correspondências íntimas com esse importante intelectual mineiro. Para o MAB, temos, até o momento, cerca de dezesseis (16) cartas pertencentes à Coleção Raul Tassini. ${ }^{20}$ Trata-se de missivas familiares trocadas entre o próprio Raul Tassini (intelectual mineiro vinculado a associações e instituições relacionadas às artes plásticas, letras, cultura e esportes de Belo Horizonte) e os seus pais e irmãos. Em suma, como as cartas em análise são autógrafas (autoria), redigidas por escreventes com amplo domínio da escrita cujas fichas sociais foram, em grande parte, pormenorizadamente levantadas, é possível entendê-las como fontes válidas dos pontos de vista social e histórico (validade social e histórica, cf. Elspass, 2012).

À título de ilustração, selecionamos alguns excertos das cartas pessoais em análise através das quais é possível entrevermos aspectos morfossintáticos que evidenciam a potencialidade desse material para futuros estudos linguísticos acerca da norma de uso do PB em sua expressão escrita entre os séculos XIX e XX.

Imagem 19 - Trecho do fac-símile da missiva redigida por RAAP. Lagoa Santa, 08.03.1917.

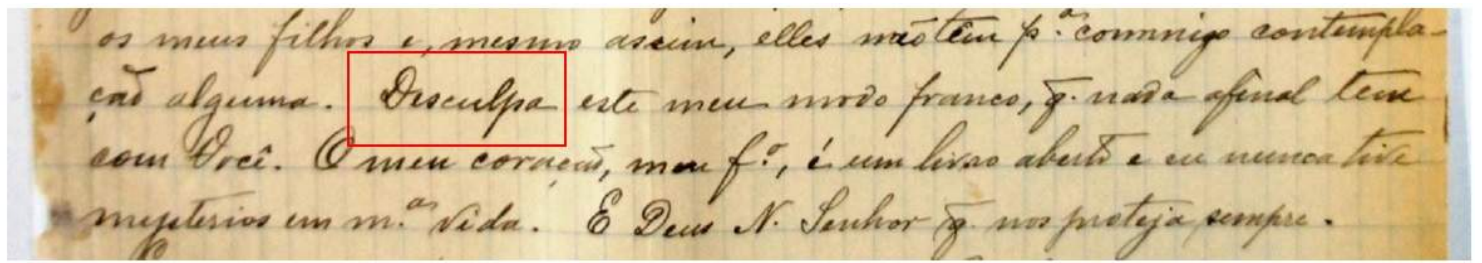

“[...] Desculpa este meu modo franco, que nada afinal tem I com você [...]”

(RAAP. Lagoa Santa, 08.03.1917.)

\footnotetext{
${ }^{18}$ No interior do AEM, temos inúmeras cartas pessoais dentre as quais destacamos as trocadas por Abgar Renault, Henriqueta Lisboa, João Alphonsus de Guimaraens, João Alphonsus de Guimaraens Filho, Carlos Drummond de Andrade, Murilo Mendes etc.

${ }^{19}$ Missivas familiares ainda em processo de transcrição por Ana Luisa Póvoa de Souza como bolsista de Iniciação Científica.

${ }^{20}$ Missivas familiares ainda em processo de transcrição por Erenildo Queiroz de Souza como aluno de Pós-Graduação (Mestrado) vinculado ao POSLIN/FALE/UFMG, tendo em vista a sua dissertação acerca da difusão do 'você' pelas relações sociais mineiras dos séculos XIX e XX.
} 
$\mathrm{Na}$ imagem $19^{21}$, temos uma evidência de uma forma imperativa vinculada ao indicativo (paradigma de $t u$ ) correlacionado a uma estrutura de prep+você ("com você"), expondo assim evidências da repercussão da inserção você como um pronome cuja referência semântica é mesmo a 2SG [-EU]. Nesse contexto, observamos que, somente através dos fac-símiles, podemos checar, no original manuscrito, a sutil interpretação das formas verbais imperativas desculpa cuja troca dos morfes [-a] por [-e] na transcrição ("desculpe" por "desculpạ") acarretaria a troca de um dado de imperativo verdadeiro (paradigma de $t u$ ) por imperativo supletivo (paradigma de você).

Imagem 20 - Trecho do fac-símile da missiva de OLR. RJ, 14.07.1951.

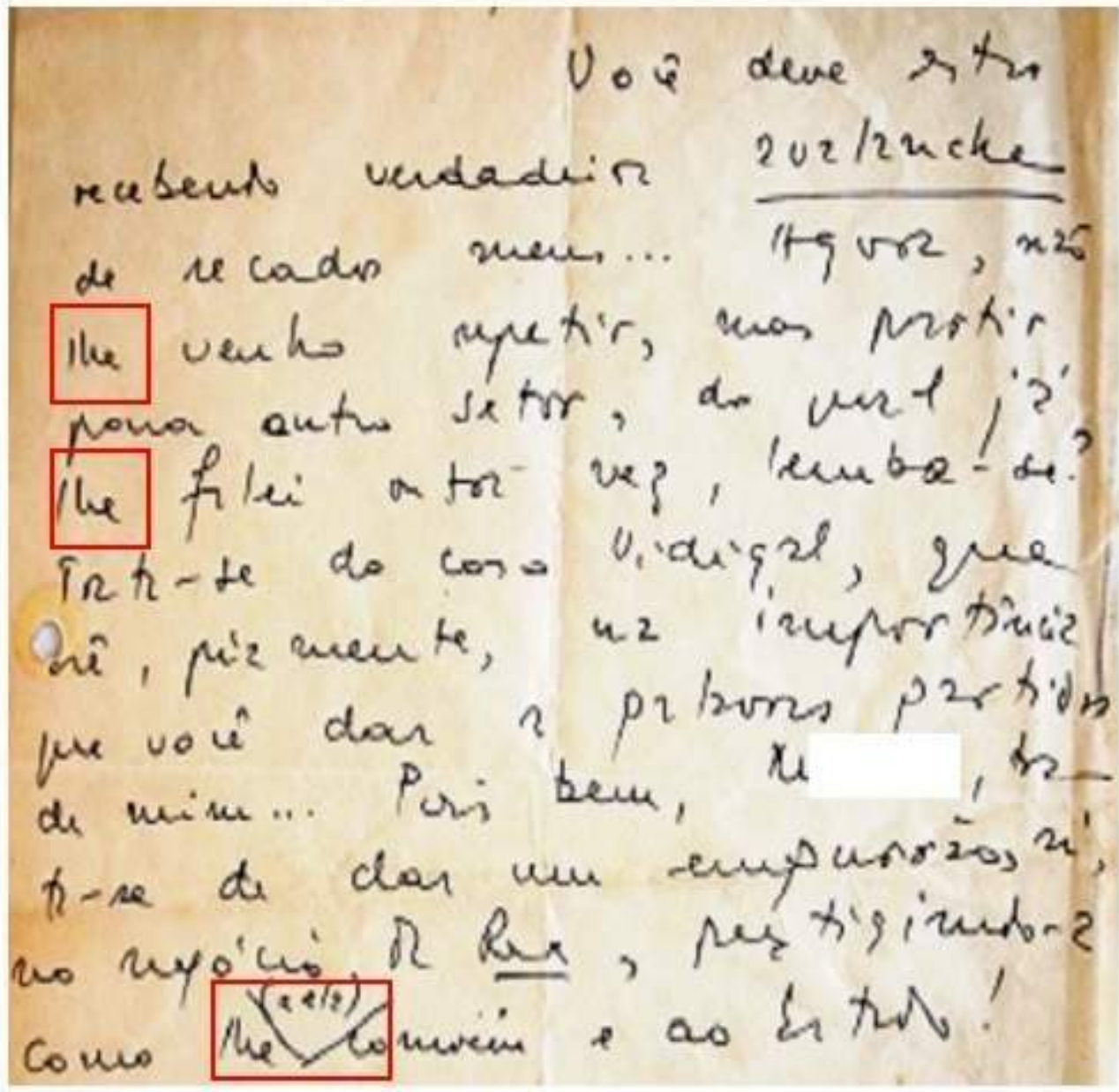

“[...] Você deve estar I recebendo verdadeira avalanche I de recados meus... I Agora, não the venho repetir, mas partir | para outro setor, do qual já I the falei certa vez, lembra-se? I Trata-se do caso Vidigal, que I crê, piamente, na importância I que você dar a palavras partidas I de mim... Pois bem, M., trata-se de dar um empurrão, aí, I no negócio da Rex, prestigiando-a $\mid$ como lhe <个(a ela)> convém e ao Estado! [...]” (OLR. RJ, 14.07.1951.)

$\mathrm{Na}$ imagem $20^{22}$, temos um excerto de uma carta mineira de você-sujeito exclusivo na referência ao sujeito de 2SG. Entretanto, observamos três dados de lhe: os dois primeiros dados de the mostram-se

\footnotetext{
${ }^{21}$ Dado discutido por Cruz (2017, p. 107).

${ }^{22}$ Dado discutido por Cruz (2017, p. 82)
} 
na referência ao interlocutor da carta $(\mathrm{MM})$, ao passo que temos, no último dado de the, uma evidência explícita feita pelo missivista a uma $3^{\text {a }}$ pessoa ("a ela"), ou seja, o autor faz referência à pessoa de quem se falava e não com quem se falava através da correspondência manuscrita. Assim sendo, para fazer-se entender em relação à oposição de usos do the (the na referência à 3SG para as duas primeiras e the na referência à $2 S G$ para a última ocorrência), o missivista (OLR) esclareceu a alusão feita, entre parênteses, a um referente fora do eixo discursivo ("a ela"), cf. ilustramos no fac-símile da carta e em sua respectiva transcrição. Em suma, observamos a referência ao interlocutor através do the (pronome complemento de $3 \mathrm{SG}$ ) que, por sua vez, funciona como um pronome complemento de 2SG, cf. discutido também por Cruz (2017).

Imagem 21 - Trecho do fac-símile da missiva de ST. BH, 18.01.1932.

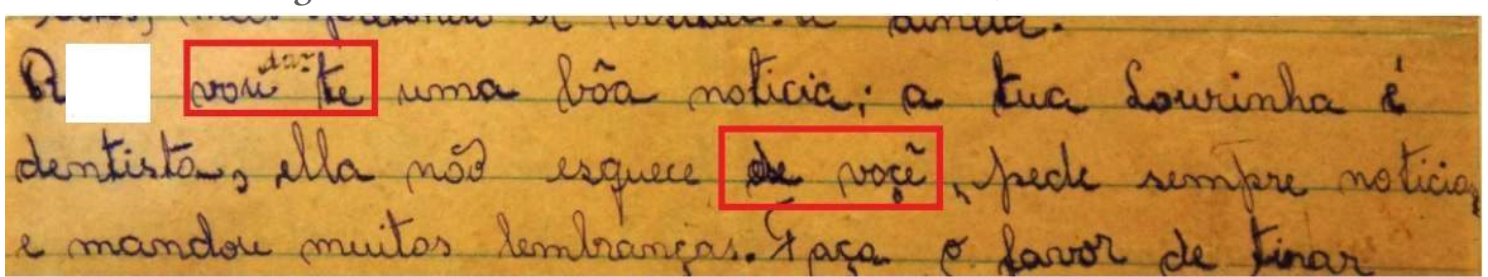

“[...] R. vou <个dar->te uma bôa noticia; a tua Laurinha é I dentista, ella não esquece de você, pede sempre noticias I e mandou muitas lembranças. Faça o favor de tirar [...]” (ST. BH, 18.01.1932)

Imagem 22 - Trecho do fac-símile da missiva de OAP. Lagoa Santa, MG, 06.06.1917.

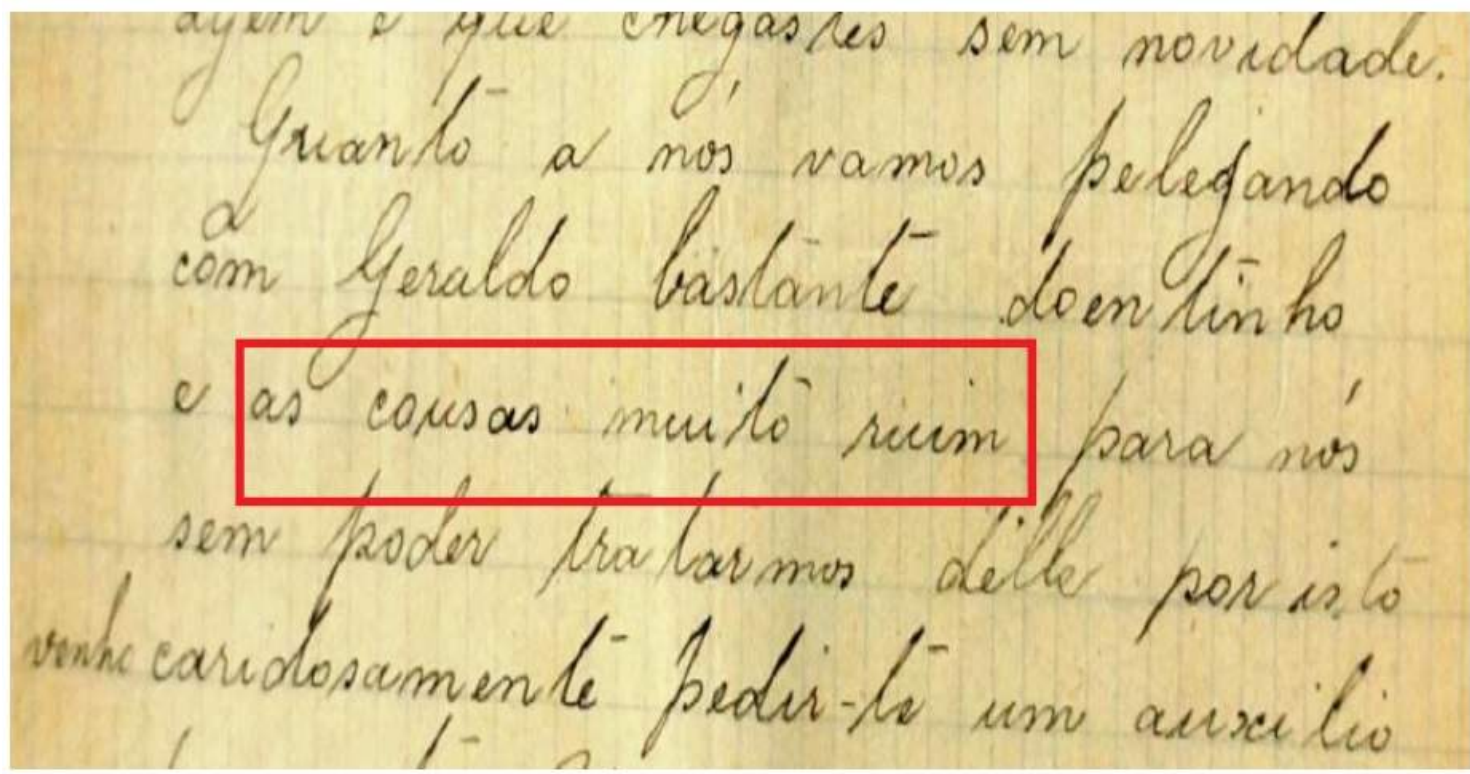

“[...] [espaço] Quanto a nós vamos pelejando | com Geraldo bastante doentinho | e as cousas muito ruim para nós $\mid$ sem poder tratarmos delle por isto | venho caridosamente perdir-te um auxilio [...]" (OAP. Lagoa Santa, MG, 06.06.1917.) 
Considerando o nível de aproximação entre os missivistas, observamos também a ausência de concordância nominal no interior do SN "as cousas muito ruim" (imagem 22) 23 que acrescentamos às demais evidências do uso do imperativo em contexto de você-complemento (imagem 19), o the como pronome-complemento de $2 \mathrm{SG}$ (imagem 20) ${ }^{24}$ e o uso dos pronomes-complemento correferentes te e você (através do sintagma preposionado de você, na imagem 21) como expressão de aspectos da norma objetiva do PB (CUNHA, 1985) que se deixam transparecer na escrita culta de sincronias passadas.

\section{Considerações finais}

Neste artigo, as experiências com manuscritos históricos oitocentistas e novecentistas ilustramnos os procedimentos adotados no trabalho de composição de corpora confiáveis às investigações linguísticas embasadas nos encaminhamentos da Socioliguística Histórica. Considerando que as fontes documentais que chegam às mãos do linguista-pesquisador costumam ser "fragmentárias, escassas e dificilmente vinculáveis com a produção real de seus falantes" ${ }^{25}$ (CONDE SILVESTRE, 2007, p. 35), não se trata da mera transposição da metodologia variacionista de base laboviana aos estudos históricos, mas da adoção de procedimentos metodológicos específicos ao trabalho com dados linguísticos de sincronias passadas.

Em suma, a obstinação do trabalho do linguista-pesquisador por fontes históricas confiáveis conduziu-nos, inspirados em Lima, Marcotulio e Rumeu (2019), aos seguintes encaminhamentos como expressão de um protocolo metodológico: $\left(1^{\circ}\right)$ identificar as questões teórico-metodológicas específicas da investigação linguística em foco, tendo em vista o seu objeto de estudo linguístico; $\left(2^{\circ}\right)$ escolher as amostras textuais relevantes aos interesses de estudo do linguista-pesquisador relacionadas às suas potencialidades (linguísticas e sociais), à extensão da amostra e ao nível de conservação de textos produzidos em sincronias passadas; $\left(3^{\circ}\right)$ levantar a ficha biográfica/social do escrevente (origem (nacionalidade, naturalidade), datas de nascimento e falecimento, filiação, grau de escolarização, função social) tanto em fontes primárias, quanto em fontes secundárias; $\left(4^{\circ}\right)$ editar conservadoramente os textos históricos.

Tendo em vista a apresentação panorâmica das amostras históricas do português escrito nos séculos XIX e XX, assumimos que as conservadoras edições de textos oficiais e não-oficiais

\footnotetext{
${ }^{23}$ Dado discutido por Cardoso (2017, p. 74).

${ }^{24}$ Dado discutido por Cruz (2017, p. 82).

25 “....) En comparación con la diversidad, cantidad y autenticidad de los datos a disposición del investigador en sociolingüística sincrónica o en lingüística descriptiva, la información de que dispone quien intenta desarrollar su investigación en el ámbito de la lingüística o la sociolingüística histórica es fragmentaria, escasa y difícilmente vinculable con la producción real de sus hablantes. (...)”, cf. Conde Silvestre (2007, p. 35).
} 
produzidos por punhos brasileiros (mineiros ou cariocas) mostram-se como relevantes fontes aos estudos linguísticos acerca da pluralidade de normas do PB (CALLOU; BARBOSA; LOPES, 2006) também em sincronias passadas.

\section{Referências bibliográficas}

ACIOLI, Vera Lúcia Costa. A escrita no Brasil colônia: um guia para a leitura de documentos manuscritos. Recife: FUNDAJ, Editora Massangana, UFPE, Editora Universitária, 1994.

ALCÂNTARA, I.R. A edição filológica de manuscritos oitocentistas da Comarca de Ouro Preto: descrição de aspectos codicológicos e paleográficos. Monografia (Graduação). Faculdade de Letras, Universidade Federal de Minas Gerais, Belo Horizonte, 2018.

AGUILAR, R.C. Presencia de lo oral en lo escrito: la transcripción de las declaraciones en documentos indianos del siglo XVI. OESTERREICHER,W.; STOLL, E.; WESCH, A. (Orgs.) Competencia escrita, tradiciones discursivas y variedades linguísticas: aspectos del español europeo y americano en los siglos XVI y XVII. Tubingen: Narr. 1998. p. 219-242.

BERGS, A. Social networks and historical sociolinguistics: studies in morphosyntactic variation in the Paston letters (1421-1503). Walter de Gruyter, 2005.

BERWANGER A.R.; LEAL J.E.F. Noções de paleografia e diplomática. $3^{a}$ ed. rev. e ampl. Santa Maria: Ed. UFSM; 2008 [1995].

BUENO, A.H.C.; BARATA, CEA. Dicionário das Famílias Brasileiras. Volumes I e II. São Paulo. 2001.

CALLOU, D.; BARBOSA, A.G.; LOPES, C.R.S. O Português do Brasil: polarização sociolinguística. In.: CARDOSO, S.A.M.; MOTA, J.A.; MATTOS E SILVA, R.V. (Orgs.). Quinhentos anos de história linguística do Brasil. Salvador: Secretaria da Cultura e Turismo do Estado da Bahia. 2006. p. 257-292.

CARDOSO, N.D. As estratégias de dativo de $2^{\mathrm{a}}$ pessoa em cartas pessoais (séculos XIX e XX). Dissertação (Mestrado em Estudos Linguísticos). Faculdade de Letras, Universidade Federal de Minas Gerais, Belo Horizonte, 2017.

CARVALHO E SILVA, M. Crítica textual: conceito - objeto - finalidade. Confluência, Rio de Janeiro, n. 7, p. 57-63, 1994.

CAVALCANTE S.R.O. Mudança e estabilidade em construções passivas na história do português. Lingüística. 2016; 32(1): 41-60.

CONDE SILVESTRE, J.C. Sociolinguística histórica. Madrid: Gredos. 2007. 
CONDÉ, V. G. As cantigas trovadorescas galego-portuguesas: uma análise filológica. In: GIL, Beatriz Daruj; CARDOSO, Elis de Almeida; CONDÉ, Valéria Gil (Orgs.) Modelos de análise linguística. São Paulo: Contexto, 2009. p. 235-249.

CUNHA, C. A Questão da Norma culta. Rio de Janeiro: Tempo Brasileiro. 1985.

COSTA, J.C. A ordem dos clíticos em complexos verbais: uma análise sociolinguística de cartas mineiras. Monografia (Graduação). Faculdade de Letras, Universidade Federal de Minas Gerais, Belo Horizonte, 2014.

CRUZ, I.A. A alternância tu/você em contextos sintáticos de complementação e de adjunção: estudo de cartas pessoais dos séculos XIX e XX. Dissertação (Mestrado em Estudos Linguísticos). Faculdade de Letras, Universidade Federal de Minas Gerais, Belo Horizonte, 2017.

DINIZ, J.S. A expressão variável do imperativo de $2^{\mathrm{a}}$ pessoa do singular no português brasileiro: análise de cartas pessoais dos séculos XIX e XX. 2018. Dissertação (Mestrado em Estudos Linguísticos). Faculdade de Letras, Universidade Federal de Minas Gerais, 2018.

ELSPASS, S. The Use of Private Letters and Diaries in Sociolinguistic Investigation. In: HERNÁNDEZ-CAMPOY, J. M.; CONDE-SILVESTRE, J. C. The Handbook of Historical Sociolinguistics. Wiley-Blackwell. 2012. p. 156-169.

FARIA, M.I.; PERICÃO, M.G. (Orgs.) Dicionário do Livro: da escrita ao livro eletrónico. Coimbra: Almedina, 2008.

FRANÇA, R.M.M. A Referência variável ao sujeito de $2^{\mathrm{a}}$ pessoa do singular em missivas mineiras: uma breve investida pelos séculos XIX e XX. Monografia (Graduação). Faculdade de Letras, Universidade Federal de Minas Gerais, Belo Horizonte, 2016.

FIGUEIREDO, R. A alternância 'Tu' e 'Você' em cartas familiares e amorosas novecentistas. Monografia (Graduação). Faculdade de Letras, Universidade Federal de Minas Gerais, Belo Horizonte, 2013.

FRANÇA, R.M.M. A referência variável ao sujeito de $2^{\mathrm{a}}$ pessoa do singular em missivas mineiras: uma breve investida pelos séculos XIX e XX. Monografia (Graduação). Faculdade de Letras, Universidade Federal de Minas Gerais, Belo Horizonte, 2016.

HERNÁNDEZ-CAMPOY, J.M.; CONDE SILVESTRE, J. The Handbook of Historical Sociolinguistics. Oxford, Wiley-Blackwell, p. 63-79, 2012.

HERNÁNDEZ-CAMPOY, J.M.; SCHILLING, N. The Application of the Quantitative Paradigm to Historical Sociolinguistics: Problems with the Generalizability Principle. In: HernándezCampoy; Conde Silvestre. The Handbook of Historical Sociolinguistics. Oxford, WileyBlackwell, p. 63-79, 2012.

LABOV, W. Principles of Linguistic Change: Internal Factors. Cambridge: Blackwell Publishers, Volume 1, 1994. 
LASMAR, J. O Instituto Histórico e Geográfico: uma História Centenária. 2a ed. Belo Horizonte: Instituto Histórico e Geográfico, 2015.

LOBO, T.C.F. Para uma sociolinguística histórica do português no Brasil. Edição filológica e análise linguística de cartas particulares do Recôncavo da Bahia, século XIX. Volume II. Tese (Doutorado em Filologia e Língua Portuguesa) - Faculdade de Filosofia, Letras e Ciências Humanas, Universidade de São Paulo, 2001.

LIMA, A.X.; MARCOTULIO, L.L.; RUMEU, M.C.B. Experiências metodológicas em constitiuição de corpora: pistas para um pesquisador iniciante. In: CASTILHO Ataliba Teixeira de. (Org.). História do português brasileiro: corpus diacrônico do português brasileiro. São Paulo: Contexto, 2019, v. 2, p. 68-91.

MARTINS, G.V.S. A edição de receitas culinárias novecentistas para o estudo do português brasileiro. Monografia (Graduação). Faculdade de Letras, Universidade Federal de Minas Gerais, Belo Horizonte, 2017.

MARTINS FILHO, A.V. Novo Dicionário Biográfico de Minas Gerais: 300 anos. Belo Horizonte: Instituto Cultural Amilcar Martins, 2013.

MARQUILHAS, R. A Faculdade das Letras: leitura e escrita em Portugal no Século XVII. Lisboa: Imprensa Nacional, Casa da Moeda. 2000.

NUÑEZ CONTRERAS, L. Manual de paleografía: fundamentos e historia de la escritura latina hasta el siglo VIII. Madrid: Cátedra; 1994.

PESSANHA, L.; COSTA, J.O; WALTER, A.; ROSENBURG, J. (Orgs.) Annaes do II Congresso Brasileiro de Instrucção Primaria e Secundaria. Belo Horizonte: Imprensa Official do Estado de Minas Geraes, 1913.

ROMAINE, S. Socio-historical linguistics: its status and methodology. Cambridge University Press. New York. 2010 [1982].

RUMEU, M.C.B. Língua e sociedade: a história do pronome 'Você' no português brasileiro. Rio de Janeiro: Ítaca (FAPERJ), 2013.

SANTIAGO-ALMEIDA, M.M. Os manuscritos e impressos antigos: a via filológica. In: GIL, Beatriz Daruj; CARDOSO, Elis de Almeida; CONDÉ, Valéria Gil (Orgs.) Modelos de análise linguística. São Paulo: Contexto, 2009. p. 223-234.

SANTOS, M.A. BISCOUTOS, ASSUCAR E CANELLA: edição filológica de receitas culinárias novecentistas. Monografia (Graduação). Faculdade de Letras, Universidade Federal de Minas Gerais, Belo Horizonte, 2018.

SILVA, F.S. Edição de atas novecentistas para o estudo da expressão escrita do português brasileiro culto. Dissertação (Mestrado em Estudos Linguísticos). Faculdade de Letras, Universidade Federal de Minas Gerais, Belo Horizonte, 2016. 
SILVA, M.R. O artífice da memória. Revista do Arquivo Público Mineiro: História e Arquivística, nº1, p. 75-91, 2007.

SPINA, S. Introdução à edótica: crítica textual. 2a ed. São Paulo: Cultrix/Edusp. 1977.

SPAGGIARI, B.; PERUGI, M. Fundamentos da crítica textual. Rio de Janeiro: Lucerna; 2004.

VASCONCELLOS, C.A.; SANTIAGO-ALMEIDA, M.M. Contribuição da Filologia e da Crítica Textual para o Estudo de Documentos Manuscritos de Paranaguá, SIGNUM: Estudos da Linguagem, Londrina, n. 15/1, p. 335-356, 2012. 